Pteridines

Vol. 5, 1994, pp. 121-128

\title{
Pteridines $\mathrm{CII}^{*}$ Synthesis and Characterization of Dimeric Lumazines
}

\author{
Ashok Koul, Thomas Wagner and Wolfgang Pfleiderer \\ Fakultät für Chemie, Universität Konstanz, Postfach 5560 D-78434 Konstanz/Germany
}

(Received June 9, 1994)

\begin{abstract}
Summary
Reduction of 1,3-dimethyllumazine (1) by zinc dust in $\mathrm{Ac}_{2} \mathrm{O} / \mathrm{AcOH}$ leads to the formation of 6-7 connected bis-lumazinyl derivatives. Depending on the reaction conditions either 7-(5-acetyl-5,6,7,8-tetrahydro-1.3-dimethyllumazin-6-yl)-1, 3-dimethyllumazin (3) or isomeric 7-(5-acetyl-5,6,7,8-tetrahydro-1, 3-dimethyllumazin6-yl)-5-acetyl-5,6,7,8-tetrahydro-1, 3-dimethyllumazines (2) are formed. Treatment of 3 with $\mathrm{MeOH} / \mathrm{HCl}$ gave 4 which is oxidized by air to a very stable 7,8 -dihydro derivative 5 showing unexpected spectra properties. Further oxidation by $\mathrm{KMnO}_{4}$ afforded 6.7-bis-1. 3-dimethyllumazinyl (6). The isomeric 6,6-(14) and 7,7-bis-1, 3-dimethyllumazinyls (21) were also synthesized from 6-chloro-(11) and 7-chloro-1, 3-dimethyllu-mazine (18), respectively, in a nickel catalyzed dimerization reaction. The various structures were proven by spectral means, elemental analyses and an X-ray analysis of $\mathbf{2}$. Comparisons of the structural features are mainly based on UV data.
\end{abstract}

\section{Introduction}

Little is known about dimeric pteridines which have been suggested as potential structures on reductive coupling reactions $(1,2)$. Mager and Berends (3) gave a first proof on the basis of mass spectral investigations that the reduction of 1,3-dimethyllumazine (1) by zinc dust in a mixture of glacial acetic acid and acetic anhydride leads to two dimeric acetylated lumazine derivatives. A direct linkage of the two nuclei through the 6 or 7 position was proposed but so far the true structures of this new type of bis-lumazinyls have not been elucidated. Since we have described the formation of 5,8-diacetyl-1,3-dimethyl-5,8-hydrolumazine $(4,5)$ on treatment of 1 either with zinc or by cathodic electrochemical reduction in acetic anhydride alone anticipating a radical mechamism we got interested in these dimers formed allegedly by slightly modified reaction conditions. Furthermore we intended to elucidate their chemical Part CI : R. Eisele, K. Aritomo and W. Pfleiderer, Pteridines 1993, 4, 178. structures by physical means and chemical transformations. These findings bear also some relationship to the reductions of pyrazine forming 1,4-diacyl -1,4-dihydropyrazines analogously $(6,7)$.

\section{Results and Discussion}

Repetition of Mager's experiment indicated by TLC that a complex mixture of compounds is formed during the applied reduction process. Tedious chromatographical separations allowed the isolation of the higher melting dimer whereas the data of the second component turned out to be different. In order to get more information about the various steps of the reductive coupling reaction less zinc dust was applied and also the reaction time was reduced to 1 hour. It was furthermore noticed that the reaction solution turned first to a yellow color which disappeared only under prolonged treatment by zinc. Work-up led to a yellow compound (3) in good yield and in form of nice crystals. We isolated obviously an intermediate since its further reduction with zinc in acetic acid/ 


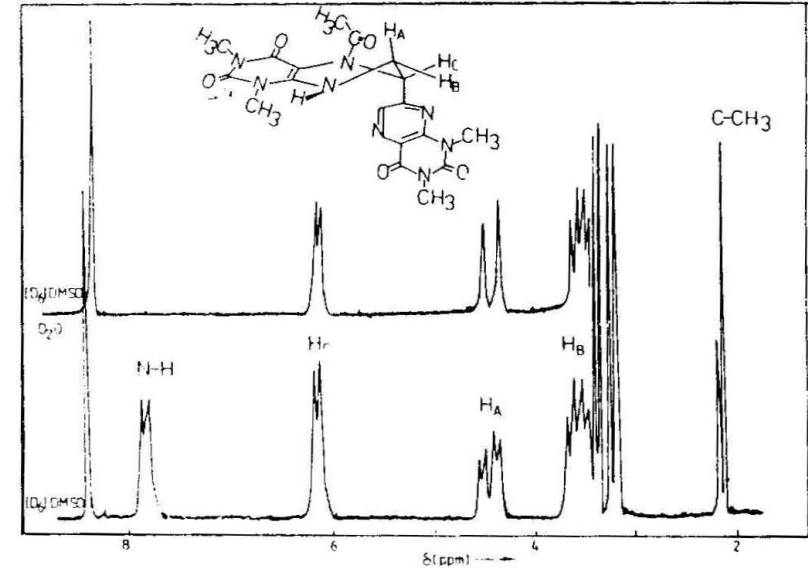

Figure 1. 'H-NMR spectrum of 3 in $\mathrm{D}_{6}$-DMSO and after H/D exchange.

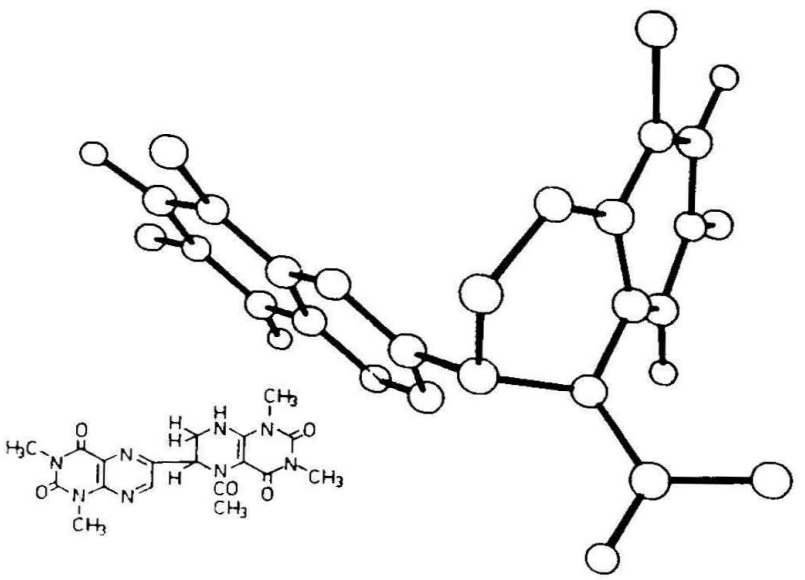

Figure 2. X-ray structure of 3.

acetic anhydride gave two colorless isomers identical with the products formed as main components in the previous experiment.

Structure of $\mathbf{3}$ could be elucidated by physical, means. The elemental analysis led to the composition $\mathrm{C}_{18} \mathrm{H}_{20} \mathrm{~N}_{8} \mathrm{O}_{5} \times \mathrm{H}_{2} \mathrm{O}$ in combination with a mass spectrum indicating a mol mass $\mathrm{m} / \mathrm{e}$ of $428\left(\mathrm{M}^{+}\right)$and a characteristic fragment of $386\left(\mathrm{M}^{+}-42\right)$ which is in agreemjent with the loss of ketene. The ${ }^{1} \mathrm{H}-\mathrm{NMR}$ spectrum (Figure 1) showed convincingly the presence of one $\mathrm{C}-\mathrm{CH}_{3}$ and 4 different $\mathrm{N}-\mathrm{CH}_{3}$ signals as expected for a dimer carrying one acetyl group. The other proton signals, however, have been puzzling to some extent since besides a singlet at $8.40 \mathrm{ppm}$ and one exchangable doublet $(\mathrm{N}-\mathrm{H})$ at $7.75 \mathrm{ppm}$ only one other doublet at $6.12 \mathrm{ppm}$ and two double doublets at 4.41 and $3.63 \mathrm{ppm}$ could be detected. This simplified spectrum is only in agrement with the proposed structure of 5-acetyl-5,6,7,8-tetrahydro-1,3-dimethyl6-(1,3-dimethyllumazin-7-yl)lumazine (3) if a special conformation eliminating by a perpendicular orien-
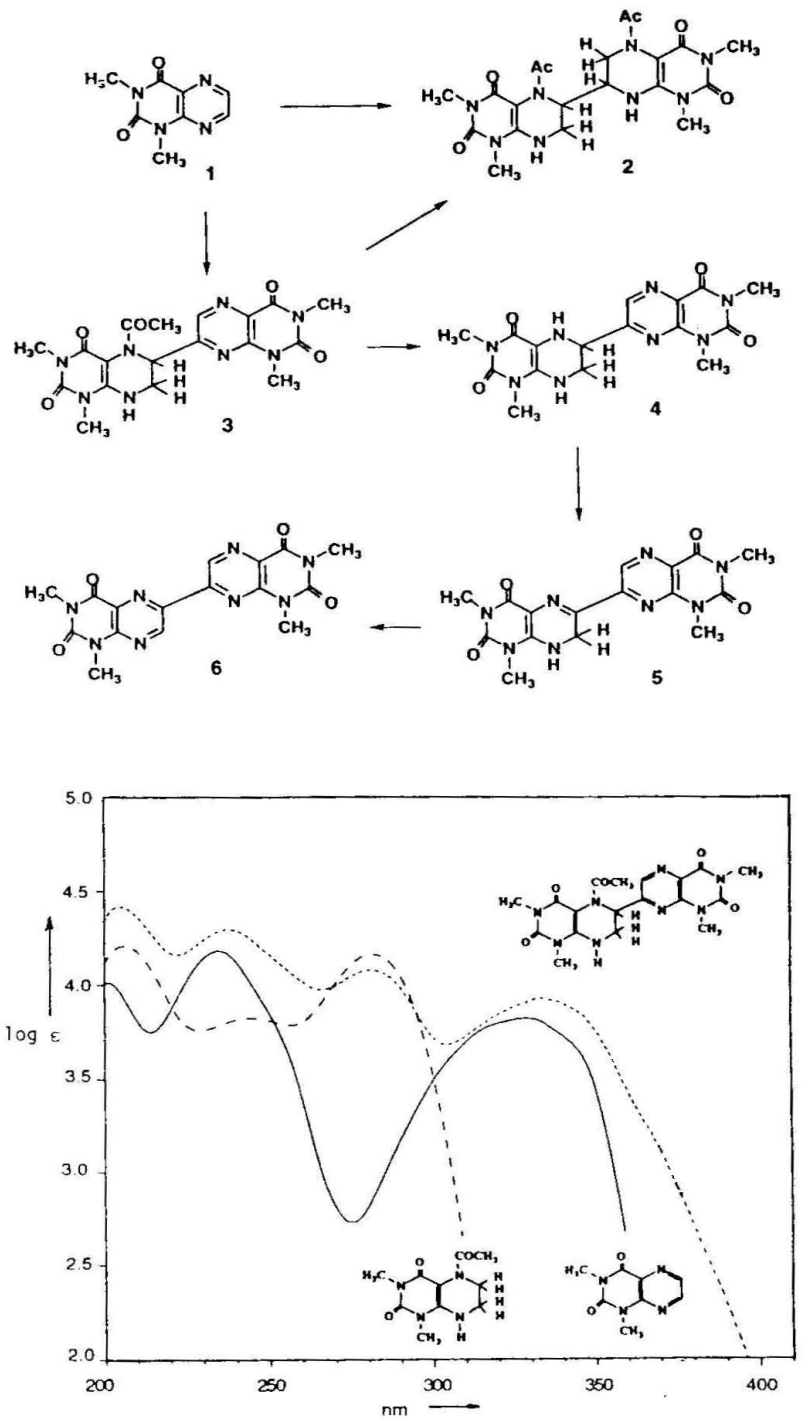

Figure 3. UV-spectra of 1(- - ), 3(-- ) and 5-acetyl-5, 6,7,8-tetrahydro-1,3-dimethyllumazine $(\cdots \cdots)$ in $\mathrm{MeOH}$.

tation the coupling of one of the diastereotopic $\mathrm{H}-\mathrm{C}$ (7A) with the adjacent $\mathrm{H}-\mathrm{C}(6)$ and the $\mathrm{N}-\mathrm{H}$, respectively. H/D exchange gives further proof of this relations. Finally the anticipated structure could then been confirmed by an X-ray analysis of $\mathbf{3}$ showing exactly the proposed structural features (Figure 2).

It is furthermore noteworthy that the UV spectrum of 3 reflects nicely its composition since the two components 5-acetyl-5,6,7,8-tetrahydro-1,3-dimethylImazine and 1,3-dimethyllumazine (1) superimpose with the dimeric structure very well as seen from the spectral comparison (Figure 3).

The formation of $\mathbf{3}$ can be explained by a radical mechanism giving rise to the regioselective $6-7$ connection of the lumazine nuclei. In the first reduction step a radical anion (7) is formed whijch is trapped 

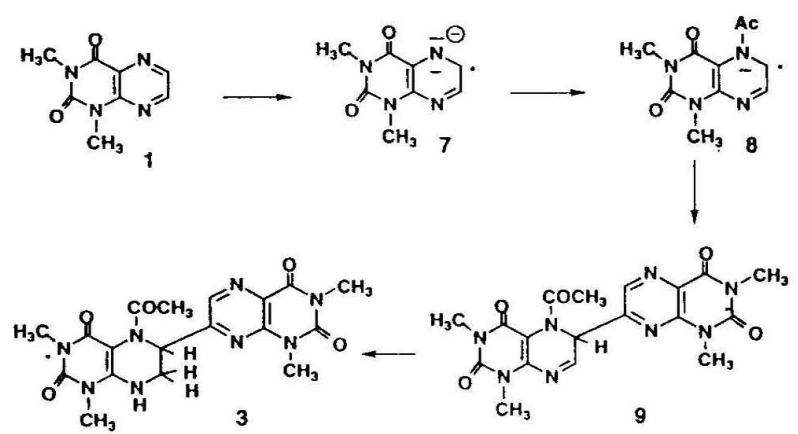

1
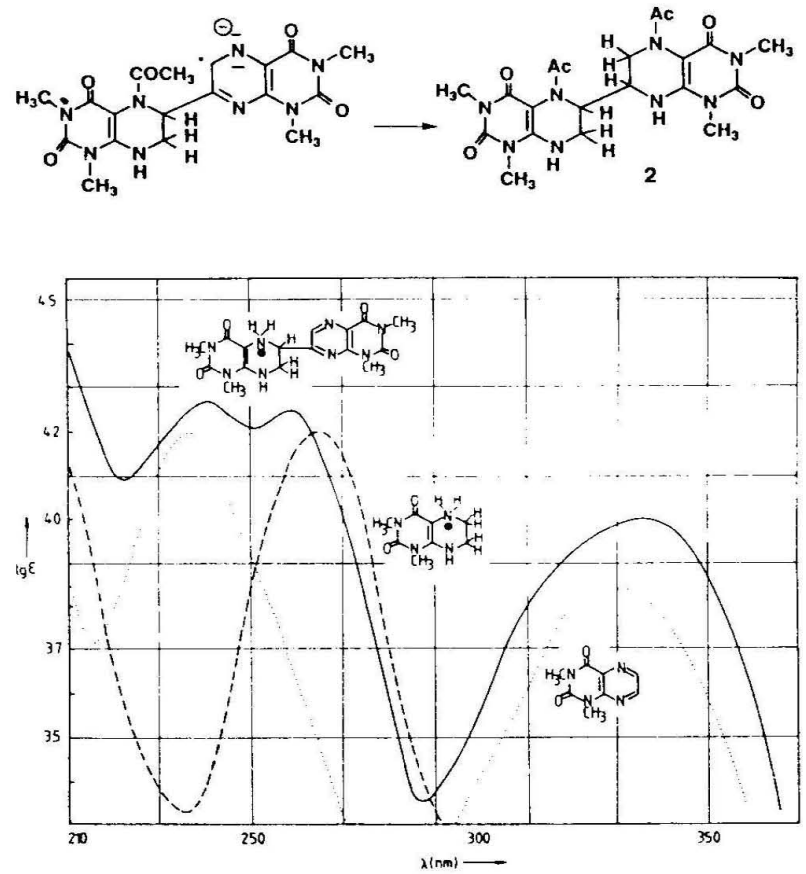

Figure 4. UV-spectra of 4, 1 and 5,6,7,8-tetrahydro-1,3-dime thyllumazine in $\mathrm{MeOH}$.

by acetylation at N-5 to give the neutral radical 8 . This radical then attacks another 1,3-dimethyllumazine molecule at position 7 in a nucleophilic radical substitution recation to 9 analogously to other radical acylations (8) which take place at the same site. Further reduction affords 3 since the partially reduced pyrazine ring will react more easily than its heteroaromatic counterpart.

Prolonged zinc treatment of 3 in $\mathrm{AcOH} / \mathrm{Ac}_{2} \mathrm{O}$ attacks also the second pyrazine ring in a similar manner which gave two 7-(5-acetyl-5,6,7,8-tetrahydro-1, 3-dimethyl-lumazin-6-yl)-5-acetyl-5,6,7,8-tetrahydro1,3-dimethyllumazines (2) identical with Mager's compounds and are most probable threo/erythro isomers regarding the central bond connection.

Further studies were concerned with the interconversion of 3 into 6,7-di-(1,3-dimethyllumazinyl) (6).

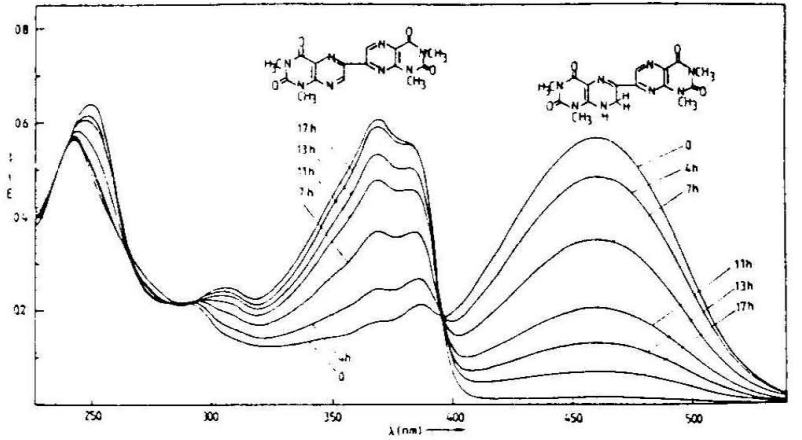

Figure 5. Autoxidation of 5 to 6 by oxygen in $\mathrm{MeOH}$.

Treatment of 3 with methanolic $\mathrm{HCl}$ afforded the monohydrochloride salt of 7-(5,6,7,8-tetrahydro-1,3dimethyllumazin-6-yl)-1,3-dimethyllumazine (4) the $\mathrm{UV}$-spectrum of which can also been regarded as a composite of 1,3-dimethyllumazine (1) the 5,6,7,8-te trahydro -1,3-dimethyllumazine cation (Figure 4).

Autoxidation of 4 resulted in the formation of a red-colored, less soluble compound showing a long wavelength absorption at $460 \mathrm{~nm}$. This spectral feature is in accordance with the 7-(7,8-dihydro-1,3-dimethyllumazin-6-yl)-1,3-dimethyl-lumazine (5) structure indicating the presence of a merocyanine chromophore extending from the $\mathrm{H}-\mathrm{N}(8)$ to the $\mathrm{C}=\mathrm{O}(4)$ function of the heteroaromatic lumazine moiety. Further oxidation of compound 5 by permanganate or more slowly by air (Figure 5 ) led to the basic molecule of this series, 7-(1,3-dimethyllumazin-6-yl)-1, 3-dimethyllumazine (6).

The ${ }^{1} \mathrm{H}$-MNR spectrum of this 6,7-dilumazine derivative indicates clearly the unsymmetrical structure of 6 in revealing $4 \mathrm{~N}-\mathrm{CH}_{3}$ and $2 \mathrm{H}-\mathrm{C}$ signals at different chemical shifts confirming additionally the proposed mechanism of formation. The assignments of the true stereochemistry to the isomeric 6,7-di(5-acetyl-5,6,7,8-tetrahydro-1,3-dimethyllumazinyls (2) was not yet possible due to the complex signal patterns of the NMR spectra. Elemental analyses and mass spectra fit with the proposed structures and the materials do not contain crystal water as observed by Mager and Berends (3).

The successful synthesis of 6,7-di-(1,3-dimethyllumazinyl) (6) forced us to synthesize also the two other symmetrical 6,6- and 7,7-isomers, respectively. The first attempt consisted of a Raney-nickel desulfurization of di-(1,3-dimethyllumazin-6- (12) and -7-yl) sulfide (19) obtained from 6- (10) and 7-bromo-1, 3dimethyllumazine (17) with thiourea. Loss of sulfur was observed under these condition but unfortunately only 1,3-dimethyllumazine (1) and no coupling to a dimer was observed. Also $\mathrm{SO}_{2}$-extrusion reactions with the oxidation products 13 and 20 from 12 and 

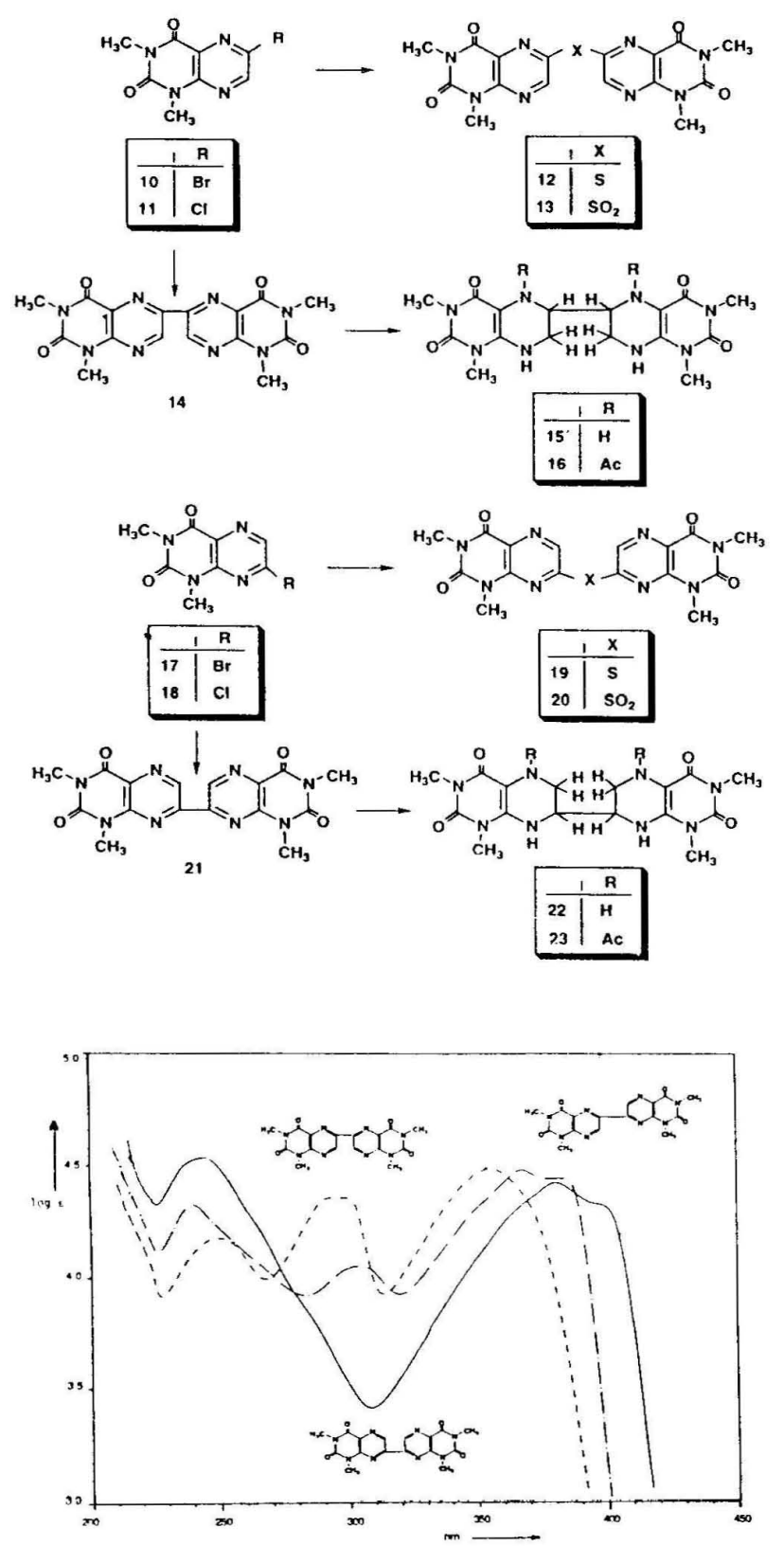

Figure 6. UV-spectra of $6\left(-^{\cdot}-^{\cdot}--^{\cdot}\right), 14(---)$ and 21 $\left(\stackrel{\longrightarrow}{\longrightarrow}\right.$ in $\mathrm{CH}_{2} \mathrm{Cl}_{2}$.

19 have not been successful. We then tried various direct coupling reactions with 6- (11) and 7-chloro1,3-dimethyllumazine (18), respectively, starting with the Ullmann reaction and applying a broad variety of reaction conditions, but without success. Also the use of organometal complexes according to Caubere (8-11) which allows to modify the CRAs (complex reducing agents) to NiCRAL, for example, did not afford any progress. Finally, the $\mathrm{Ni}\left(\mathrm{PPh}_{3}\right)_{4}$ complex, prepared from nickel chloride and triphenylphosphane in DMF by treatment with zinc powder at $50^{\circ} \mathrm{C}$ analogous to Tiecco et al. (12-14), initiated the anti- cipate coupling reaction in the expected manner. The yield of the dilumazinyl dimer formation is dependent on the reaction conditions since 11 gave at $50^{\circ} \mathrm{C}$ in 2.5 hours $63 \%$ of 14 and 18 reacted similarly at $70^{\circ} \mathrm{C}$ within 1.5 hours also to a $63 \%$ isolated yield of $\mathbf{2 1}$. Reaction of a 1:1 mixture of 11 and 18 led as expected to a mixture of three compounds which were separated by tedious chromatographical means on preparative silica gel plates into three components identical with the dimers 6,14 and 21 . The ${ }^{1} \mathrm{H}$-NMR spectra of 14 and 21 are very simple and show only one $\mathrm{H}-\mathrm{C}$ and two $\mathrm{N}-\mathrm{CH}_{3}$ signals as expected from the symmetry in the structures. The UV spectra exhibit similarities in the long wavelength region with redshifts from 14 to 6 to 21, respectively (Figure 6).

Catalytic reduction of 14 and 21 afforded the corresponding octahydro derivatives $\mathbf{1 5}$ and 22 and subsequent acetylation by acetic anhydride led to stereoisomeric mixtures of di-(5-acetyl-5,6,7,8-tetrahydro-1,3-dimethyllumazin-6- (16) and -7-yl) (23), respectively. The UV spectra fit very well with the monomeric 5-acetyl-5,6,7,8-tetrahydro-1,3-methyllumazine (15) but the NMR spectra are of complex nature to be analysed completely.

\section{Experimental Part}

General :-TLC : precoated silica gel thin-layer sheets F 1500 LS 254 and cellulose thin-layer sheets F 1440 LS 254 from Schleicher \& Schüll. Prep. plates $20 \times 20 \times 0.2 \mathrm{~cm}$ silica gel $\mathrm{PF}_{254}$ from Merck. M.p. : Büchi apparatus, model Dr. Tottuli; no corrections. UV/VIS : Lambda 5 (Perkin Elmer); $\lambda \max (\log \varepsilon)$ in nm; [ ] shoulder.. 'H-NMR : Bruker WN-250; in $\delta$ (ppm) relative to TMS. MS : Finnigan MAT 312.

\section{1,3-Dimethyllumazine (1) (16)}

Heating of $0.1 \mathrm{~g}$ of either 12 or $19 \mathrm{in} 50 \mathrm{ml}$ of DMF with $4 \mathrm{~g}$ of wet Raneynickel for 1 hour afforded desulfurization. The catalyst was filtered off, DMF removed in vacuum and the residue recrystallized from little water to give $0.07 \mathrm{~g}(75 \%)$ of colorless crystals of m.p. $200^{\circ}$. The product is chromatographically identical with authentic 1,3-dimethyllumazine.

\section{7-(5-Acetyl-5,6,7,8-tetrahydro-1,3-dimethyllumazin-6- yl)-5-acetyl-5,6,7,8-tetrahydro-1,3-dimethyllumazine (2)}

a) In a mixture of $50 \mathrm{ml}$ of $\mathrm{AcOH}$ and $50 \mathrm{ml}$ of $\mathrm{Ac}_{2} \mathrm{O}$ were dissolved $5 \mathrm{~g}$ of 1,3-dimethyllumazine (1) and then under boiling $7 \mathrm{~g}$ of zinc dust added gradually within 2 hours. After heating for another hour the insoluble precipitate was filtered off, the filtrate 
evaporated and the residue coevaporated twice with $\mathrm{EtOH}$. The solid was treated with $25 \mathrm{ml}$ of hot acetone and filtered from little insoluble material. The filtrate was stored for 2 days whereby a precipitate $(1.1 \mathrm{~g})$ separated slowly. Two recrystallizations from EtOH gave $0.77 \mathrm{~g}(13 \%)$ colorless crystals of m.p.> $320^{\circ}$. Rf $\left(\mathrm{CHCl}_{3} / \mathrm{MeOH} 4 / 1\right) 0.15$. UV $(\mathrm{MeOH}):[2$ 43, (4.04)], 282 (4.31). MS : $474\left(\mathrm{M}^{+}\right), 432\left(\mathrm{M}^{+}-\mathrm{CH}_{2}\right.$ CO). Anal. calc. for $\mathrm{C}_{20} \mathrm{H}_{26} \mathrm{~N}_{8} \mathrm{O}_{6}$ (474.5) : $\mathrm{C} 50.80$, H 5.55, N23.32; found : C50.46, H5.65, N23.21.

Evaporation of the acetone filtrate and crystallization of the residue from $15 \mathrm{ml}$ of $\mathrm{MeOH}$ gave $0.45 \mathrm{~g}$ which was further recrystallized from $50 \mathrm{ml}$ of EtOH to give $0.26 \mathrm{~g} \mathrm{(4 \% )}$ of the second component as colorless crystals of m.p. $>320^{\circ}$. $\mathrm{Rf}\left(\mathrm{CHCl}_{3} / \mathrm{MeOH}\right.$ 4:1) 0.40. UV (MeOH) : [243 (4.05)], 282 (4.29). MS : $474\left(\mathrm{M}^{+}\right), 432\left(\mathrm{M}^{+}-\mathrm{CH}_{2} \mathrm{CO}\right)$. Anal. calc. for $\mathrm{C}_{20} \mathrm{H}_{26}$ $\mathrm{N}_{8} \mathrm{O}_{6}$ (474.5) : C50.80, H5.55, N23.32; found : C50.39, H5.60, N22.95.

b) In a mixture of $10 \mathrm{ml}$ of $\mathrm{AcOH}$ and $10 \mathrm{ml}$ of $\mathrm{Ac}_{2} \mathrm{O} 0.6 \mathrm{~g}$ of 7-(5-acetyl-5,6,7,8-tetrahydro-1,3-dimethyllumazin-6-yl)-1,3-dimethyllumazine (3) were heated under reflux and then gradually $0.5 \mathrm{~g}$ of zinc dust added within $15 \mathrm{~min}$. After boiling for 1 hour and cooling to room temperature was filtered from the zinc salts and the filtrate evaporated and then coevaporated with $\mathrm{EtOH}$ to dryness. The residue was treated with little $\mathrm{MeOH}$ to give $0.30 \mathrm{~g}$ of a substance mixture according to TLC. Purification was performed by chromatographical separation on preparative silica gel plates in $\mathrm{CHCl}_{3} / \mathrm{MeOH}$ 9/1. The two main bands have been eluted and gave on evaporation the two isomers 2, which have been chromatographically and spectrophotometrically identical with the two compounds described under a).

c) A solution of $0.1 \mathrm{~g}$ of 3 was dissolved in $20 \mathrm{ml}$ of $\mathrm{H}_{2} \mathrm{O}, 50 \mathrm{mg} \mathrm{PtO}_{2}$ added and reduced under $\mathrm{H}_{2}$ atmosphere in a shaking apparatus till two equivalents of $\mathrm{H}_{2}$ were consumed. The catalyst was filtered off under Ar atmosphere, the filtrate evaporated to dryness and the residue treated with $5 \mathrm{ml}$ of $\mathrm{Ac}_{2} \mathrm{O}$. After stirring for 2 hours was evaporated again and the residue, consisting of two isomers 2 again, separated by preparative silica gel chromatography as described under $b$ ).

\section{7-(5-Acetyl-5,6,7,8-tetrahydro-1,3-dimethyllumazin-6- yl)-1,3-dimethyllumazine (3)}

In a mixture of $35 \mathrm{ml}$ of $\mathrm{AcOH}$ and $35 \mathrm{ml}$ of $\mathrm{Ac}_{2} \mathrm{O}$ were heated $3,5 \mathrm{~g}(0.0175 \mathrm{~mol})$ of 1,3-dimethyllumazine (1) under reflux and then $1 \mathrm{~g}$ of zinc dust added gradually in small portions within 1 hours. After heating for 3 hours the precipitate was filtered hot, washed twice with hot $\mathrm{AcOH}$ and then the united filtrates evaporated in vacuum. The residue was treated with $80 \mathrm{ml}$ of acetone to give $1.33 \mathrm{~g}$ of a crude yellow material. Recrystallization from $300 \mathrm{ml}$ of $\mathrm{H}_{2} \mathrm{O}$ gave $0.92 \mathrm{~g}(24 \%)$ of yellowish crystals of m.p. $>310^{\circ}$ (decomp.). UV (MeOH) : 239 (4.28), 283 (4.08), 334 (3.93). MS : $428\left(\mathrm{M}^{+}\right), 386\left(\mathrm{M}^{+}-\mathrm{CH}_{2} \mathrm{CO}\right)$. ${ }^{1} \mathrm{H}-\mathrm{NMR}$ (D6-DMSO) : 8.40 (s, 1H, H-C(6)); 7.75 (d, $\mathrm{J}=4 \mathrm{~Hz}, 1 \mathrm{H}, \mathrm{H}-\mathrm{N}) ; 6.12\left(\mathrm{~d}, \mathrm{~J}=5 \mathrm{~Hz}, 1 \mathrm{H}, \mathrm{H}-\mathrm{C}\left(6^{\prime}\right)\right.$; 4.41 (dd, J=12 Hz, J=5 Hz, 1H, H-C(7'); 3.63 (dd, $\mathrm{J}=12 \mathrm{~Hz}, \mathrm{~J}=4 \mathrm{~Hz}, 1 \mathrm{H}, \mathrm{H}-\mathrm{C}(7$ )); 3.61 (s, 3H, N-CH3); 3.29 (s, 3H, N-CH $)$; 3.17 (s, 3H, N-CH $; 3.11$ (s, $3 \mathrm{H}$, $\left.\mathrm{N}-\mathrm{CH}_{3}\right) ; 2,13$ (s, $\left.3 \mathrm{H}, \mathrm{COCH}_{3}\right)$, Anal. calc. for $\mathrm{C}_{18} \mathrm{H}_{20}$ $\mathrm{N}_{8} \mathrm{O}_{5} \mathrm{xH}_{2} \mathrm{O}$ (446.3) : C48.44, H4.97, N25.11; found : C 48.23, H4.89, N25.29.

\section{7-(5,6,7,8-Tetrahydro-1,3-dimethyllumazin-6-yl)-1,3- dimethyllumazine hydrochloride (4)}

In $20 \mathrm{ml}$ of a saturated solution of methanolic $\mathrm{HCl}$ $0.5 \mathrm{~g}$ (1.12 mmol) of 3 were refluxed for 1 hour. It was evapotated to dryness and the residue treated with $\mathrm{MeOH} / \mathrm{ether}$ to give $0.47 \mathrm{~g}(95 \%)$ of a colorless crystal powder of m.p. $>330^{\circ}$. LT pH $1: 241$ (4.27), 259 (4.23), 337 (4.00).; pH 6.0 : 236 (4.32), 310 (4.15), [330 (4.09)]; pK : 2.37; MS : $386\left(\mathrm{M}^{-}\right)$. 'H-NMR (D6-DMSO) : Anal. calc. for $\mathrm{C}_{16} \mathrm{H}_{18} \mathrm{~N}_{8} \mathrm{O}_{4} . \mathrm{HCl} . \mathrm{H}_{2} \mathrm{O}$ (440.8) : C43.59, H4.80, N25.42; found : C43.30, H 4.68, N25.61.

\section{7-(7,8-Dihydro-1, 3-dimethyllumazin-6-yl)-1,3-dimethyl- lumazine (5)}

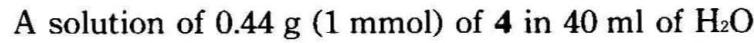
was stirred at room temperature for 3 days while a slow stream of oxygen was bubbled throught the reaction solution. An orange colored precipitate separated and was collected. The less soluble material was treated with hot $\mathrm{MeOH}$, filtered and dried in the oven at $100^{\circ}$ to give $0.276 \mathrm{~g}(72 \%)$ of an orange powder of m.p. $>330^{\circ}$. UV $(\mathrm{MeOH}): 249$ (4.40), [285 (3.92)], 335 (3.58); 460 (4.39). pH 7.0 : 249 (4.38), [285 (3.95)], [370 (3.84)], 390 (3.92), 459 (4.31); pH $13: 227$ (4.29), 282 (4.18), 350 (3.87), [384 (3.72)], 545 (4.30); pK : 10.51; ' $\mathrm{H}-\mathrm{NMR}\left(\mathrm{D}_{6-}\right.$ DMSO) : 9.14 (s, $1 \mathrm{H}, \mathrm{H}-\mathrm{C}(6)) ; 7.94$ (bs, 1H, H-N); 4.59 (s, 2H, H-C(7)); 3.58 (s, 3H, N-CH $) ; 3.36$ (s, $3 \mathrm{H}, \mathrm{N}-\mathrm{CH}_{3}$ ); 3.33 (s, 3H, N-CH $) ; 3.22$ (s, 3H, N-CH $)$. Anal. calc. for $\mathrm{C}_{16} \mathrm{H}_{16} \mathrm{~N}_{8} \mathrm{O}_{4}(384.4)$ : $\mathrm{C} 49.99, \mathrm{H} 4.20, \mathrm{~N}$ 29.16; found : C49.96, H3.91, N29.49.

\section{7-(1,3-Dimethyllumazin-6-yl)-1,3-dimethyllumazine(6)}

a) A solution of $0.22 \mathrm{~g}(0.5 \mathrm{mmol})$ of 4 in $23 \mathrm{ml}$ 
of DMF was heated to $60^{\circ}$ and under stirring $2 \mathrm{ml}$ of $30 \% \mathrm{H}_{2} \mathrm{O}_{2}$ gradually added. After stirring over night $20 \mathrm{ml}$ of $\mathrm{H}_{2} \mathrm{O}$ was added and the precipitate collected. Recrystallization from DMF with little charcoal gave $0.145 \mathrm{~g}(76 \%)$ of yellowish crystals of m.p. $>330^{\circ}$.

b) A solution of $0.22 \mathrm{~g}(0.5 \mathrm{mmol})$ of 4 in $50 \mathrm{ml}$ of $\mathrm{H}_{2} \mathrm{O}$ was oxidized under stirring by dropwise addition of $0.15 \mathrm{~g} \mathrm{KMnO}_{4}$ in $20 \mathrm{ml}$ of $\mathrm{H}_{2} \mathrm{O}$. The mixture was heated to $50^{\circ}$ for 2 hours and then the precipitate $\left(\mathrm{MnO}_{2}+\right.$ substance) collected. After drying the solid was continously extracted by $\mathrm{CHCl}_{3}$ in a Soxhlet apparatus for 2 days. The $\mathrm{CHCl}_{3}$ extract was evaporated to dryness and the residue recrystallized from DMF under addition of little $\mathrm{H}_{2} \mathrm{O}$ to give $0.14 \mathrm{~g}(73 \%)$ of yellowish crystals of m.p. $>330^{\circ}$. UV $\left(\mathrm{CH}_{2} \mathrm{Cl}_{2}\right): 242$ (4.34), 304 (4.05), 371 (4.47), [390 (4.44)]. $\mathrm{MeOH}: 211$ (4.32), 241 (4.34), 304 (4.03), 369 (4.47), [381 (4.44)]. MS : $382\left(\mathrm{M}^{+}\right) .{ }^{1} \mathrm{H}-\mathrm{NMR}\left(\mathrm{D}_{6}\right.$-DMSO) : $9.70(\mathrm{~s}, 1 \mathrm{H}, \mathrm{H}-$ $\mathrm{C}(7)) ; 9.36$ (s, $1 \mathrm{H}, \mathrm{H}-\mathrm{C}(6)) ; 3.72$ (s, $\left.3 \mathrm{H}, \mathrm{N}-\mathrm{CH}_{3}\right) ; 3.66$ (s, $\left.3 \mathrm{H}, \mathrm{N}-\mathrm{CH}_{3}\right) ; 3.42$ (s, $\left.3 \mathrm{H}, \mathrm{N}-\mathrm{CH}_{3}\right) ; 3.40$ (s, $3 \mathrm{H}, \mathrm{N}$ $\mathrm{CH}_{3}$ ). Anal. calc. for a $\mathrm{C}_{16} \mathrm{H}_{14} \mathrm{~N}_{8} \mathrm{O}_{4}$ (382.3) : $\mathrm{C} 50.26$, H3.69, N29.31; found : C50.15, H3.69, N29.20.

\section{Bis (1,3-dimethyllumazin-6-yl)-sulfide (12)}

A mixture of $0.82 \mathrm{~g}$ ( $3 \mathrm{nmol})$ of 6-bromo-1.3-dimethyllumazine (10) (17) and $0.5 \mathrm{~g}$ thiourea were refluxed in $40 \mathrm{ml}$ of $\mathrm{EtOH}$ for 24 hours. The precipitate was collected and gave after drying at $100^{\circ} 0.32 \mathrm{~g}$ (51\%) of a yellowish crystal powder of m.p. 308 $310^{\circ}$. UV (MeOH) : 245 (4.35), 269 (4.34), 360 (4.11). ${ }^{1} \mathrm{H}-\mathrm{NMR}$ (D6-DMSO) : 9.00 (s, 2H, H-C (7)); 3.92 (s, $3 \mathrm{H}, \mathrm{N}-\mathrm{CH}_{3}$ ); 3.68 (s, $3 \mathrm{H}, \mathrm{N}-\mathrm{CH}_{3}$ ). Anal. calc. for $\mathrm{C}_{16}$ $\mathrm{H}_{14} \mathrm{~N}_{8} \mathrm{O}_{4} \mathrm{~S}$ (414.3) : C46.38, H3.40, N27.03; found : C 46.40, H3.43, N27.06.

\section{Bis-(1,3-dimethyllumazin-6-yl)-sulfone (13)}

A solution of $0.2 \mathrm{~g}$ of $\mathbf{1 2}$ in trifluoroacetic acid and a solution of $20 \mathrm{mg}$ of $\mathrm{Na}_{2} \mathrm{WO}_{4} \times 2 \mathrm{H}_{2} \mathrm{O}$ were united and to the resulting suspension $4 \mathrm{ml}$ of $30 \% \mathrm{H}_{2} \mathrm{O}_{2}$ added dropwise. After stirring for 2 hours the clear solution was evaporated and then the residue treated with $20 \mathrm{ml}$ of $\mathrm{H}_{2} \mathrm{O}$ to form a crystalline solid. Washing with EtOH and drying yielded $0.185 \mathrm{~g}(85 \%)$ of yellowish crystals of m.p. $>340^{\circ}$. UV $\left(\mathrm{CH}_{3} \mathrm{CN}\right): 253(4.47)$, [275 (4.33)], 336 (4.26). MS : $446\left(\mathrm{M}^{+}\right) .{ }^{1} \mathrm{H}-\mathrm{NMR}$ (DTFA) : 9.74 (s, 2H, H-C $\left.\left(7,7^{\prime}\right)\right) ; 3.95$ (s, $\left.6 \mathrm{H}, \mathrm{N}-\mathrm{CH}_{3}\right)$; 3.66 (s, $6 \mathrm{H}, \mathrm{N}-\mathrm{CH}_{3}$ ). Anal. calc. for $\mathrm{C}_{16} \mathrm{H}_{14} \mathrm{~N}_{8} \mathrm{O}_{6} \mathrm{SxH}_{2} \mathrm{O}$ (446.3) : C41.38, H3.74, N24.13; found : C41.41, H3.43, N24.21.

\section{Bis-(1,3-dimethyllumazin-6-yl) (14)}

To a solution of $0.48 \mathrm{~g}$ of $\mathrm{NiCl}_{2} \times 6 \mathrm{H}_{2} \mathrm{O}$ in $30 \mathrm{ml}$ of
DMF $2.08 \mathrm{~g}$ of triphenyl-phosphane was added whereby the dark green color changed to dark blue. The solution was heated to $50^{\circ}$ and under nitrogen atmosphere $0.13 \mathrm{~g}$ zinc powder added gradually. After 1 hour of stirring $0.45 \mathrm{~g}(2 \mathrm{mmol})$ of 6 -chloro-1,3-dimethyl-lumazine (11) (17) were added and after treatment for another 2.5 hours at $50^{\circ}$ the warm reaction solution poured into $100 \mathrm{ml}$ of $1 \mathrm{~N}$ ammonia. The resulting suspension was shaken twice with $200 \mathrm{ml}$ of ether and then extracted continuously in a perforator with $\mathrm{CHCl}_{3}$ over night. The $\mathrm{CHCl}_{3}$-phase was dried over $\mathrm{Na}_{2} \mathrm{SO}_{4}$, evaporated and the residue recrystallized from $140 \mathrm{ml}$ of $\mathrm{DMF}+7 \mathrm{ml}$ of $\mathrm{H}_{2} \mathrm{O}$ to give $0.24 \mathrm{~g}(63 \%)$ of a yellowish crystal powder of m.p.>350॰. UV $\left(\mathrm{CH}_{2} \mathrm{Cl}_{2}\right): 250$ (4.18), 300 (4.38), 356 (4.50). MS : $382\left(\mathrm{M}^{+}\right) .{ }^{1} \mathrm{H}-\mathrm{NMR}$ (D-TFA) : 10.07 (s, 2H, $\mathrm{H}-\mathrm{C}\left(7,7^{\prime}\right)$ ); 4.00 (s, $\left.6 \mathrm{H}, \mathrm{N}-\mathrm{CH}_{3}\right) ; 3.79$ (s, 6H, N-CH3). Anal. calc. for $\mathrm{C}_{16} \mathrm{H}_{14} \mathrm{~N}_{8} \mathrm{O}_{4}(382.3)$ : $\mathrm{C} 50.26, \mathrm{H} 3.69, \mathrm{~N}$ 29.31; found : C50.28, H3.75, N29.32.

\section{Bis-(5,6,7,8-tetrahydro-1,3-dimejthyllumazin-6-yl) Dihy- drochloride (15)}

In $20 \mathrm{ml}$ of TFA $40 \mathrm{mg}$ of $\mathrm{PtO}_{2}$ were reduced in a shaking apparatus under hydrogen atmosphere. Then a solution of $0.191 \mathrm{~g}(0.5 \mathrm{mmol})$ of 14 in $30 \mathrm{ml}$ of TFA added and the reduction continued for 8 hours. It was filtered from the catalyst and the filtrate added slowly with stirring into methanolic $\mathrm{HCl}$. The mixture was evaporated to dryness and the residue treated with ether. The precipitate was collected, treated with $\mathrm{MeOH}$ again and then ether added dropwise to give after drying $0.118(51 \%)$ of a colorless powder of m.p. $>310^{\circ}$ (decomp.). UV ( $\mathrm{pH} \mathrm{0.0):205}$ (4.40), 265 (4.39); (pH7) : 237 (4.08), 299 (4.25). MS : $390\left(\mathrm{M}^{+}\right)$. Anal. calc. for $\mathrm{C}_{16} \mathrm{H}_{22} \mathrm{~N}_{8} \mathrm{O}_{4} \times 2 \mathrm{HCl} \times 2 \mathrm{H}_{2} \mathrm{O}$ (499.3) : C38.38, H5.65, N22.44; found : C38.16, H5.42, N22.48.

\section{Bis-(5-acetyl-5,6,7,8-tetrahhdro-1,3-dimethyllumazin-6- yl) (16)}

In TFA were reduced $0.19 \mathrm{~g}(0.5 \mathrm{mmol})$ of 14 analogously to the preceeding procedure. After evaporation to dryness $20 \mathrm{ml}$ of $\mathrm{Ac}_{2} \mathrm{O}$ was added and the mixture heated under gentle reflux for $30 \mathrm{~min}$. Again evaporation to dryness and recrystallization of the residue from $\mathrm{H}_{2} \mathrm{O}$ gave $0.147 \mathrm{~g}(62 \%)$ of colorless crystals of m.p. $>330^{\circ}$. UV $(\mathrm{MeOH}): 207$ (4.20), [250 (3.79)], 281 (4.21). MS : $474\left(\mathrm{M}^{+}\right)$. Anal.calc. for a $\mathrm{C}_{20}$ $\mathrm{H}_{26} \mathrm{~N}_{8} \mathrm{O}_{6} \times 2 \mathrm{H}_{2} \mathrm{O}(510.5): \mathrm{C} 47.05, \mathrm{H} 5.95, \mathrm{~N} 21.95$; found : C47.19, H5.76, N22.11.

Bis-(1,3-dimethyllumazin-7-yl)-sulfide (19) 
a) A mixture of $0.82 \mathrm{~g}(3 \mathrm{mmol})$ of 7 -bromo-1, 3dimethyllumazine (17) (17) and $0.5 \mathrm{~g}$ thiourea in 40 $\mathrm{ml}$ of EtOH was refluxed for 5 hours. During the reaction 5 drops of triethylamine were added. After cooling the precipitate was collected, washed and dried at $100^{\circ}$ to give $0.38 \mathrm{~g}(61 \%)$ of a yellowish powder of m.p. $>275^{\circ}$ (decomp.).

b) A mixture of $0.224 \mathrm{~g}(1 \mathrm{mmol})$ of 7 -mercapto-1, 3-dimethyllumazine (18) and $0.276 \mathrm{~g}(1 \mathrm{mmol})$ of 7 bromo-1,3-dimethyllumazine (17) in $30 \mathrm{ml}$ of $\mathrm{EtOH}$ was heated under reflux for 4 hours. During the reaction 5 drops of triethylamine were added gradually. The precipitate as collected, washed with EtOH and dried to give $0.397 \mathrm{~g}(96 \%)$ of a chromatographically pure yellowish powder of m.p. $>275^{\circ}$ (decomp.).

c) A mixture of $0.67 \mathrm{~g}(3 \mathrm{mmol})$ of 7-chloro-1,3-dimethyllumazine (18) (17) and $0.5 \mathrm{~g}$ of thiourea was refluxed for 8 hours under gradual addition of 5 drops of triethylamine. The resulting precipitate was collected, washed with $\mathrm{EtOH}$ and dried to give $0.58 \mathrm{~g}$ (93\%) of a yellowish powder of m.p. $>275^{\circ}$ (decomp.). UV $\left(\mathrm{CH}_{2} \mathrm{Cl}_{2}\right): 228$ (4.43), [346 (4.20)], 376 (4.42). ${ }^{1} \mathrm{H}-\mathrm{NMR}\left(\mathrm{D}_{6}\right.$-DMSO) : 8.98 (s, 2H, H-C $(6)$ ); 3.74 (s, $3 \mathrm{H}, \mathrm{N}-\mathrm{CH}_{3}$ ); 3.66 (s, 3H, N-CH 3 ). Anal. calc. for $\mathrm{C}_{16}$ $\mathrm{H}_{14} \mathrm{~N}_{8} \mathrm{O}_{4} \mathrm{~S}$ (414.3) : C46.38, H3.40, N27.06; found : C 46.55, H3.42, N27.06.

\section{Bis-(1,3-dimethyllumazin-7-yl)-sulfone (20)}

Solutions of $0.207 \mathrm{~g}(0.5 \mathrm{mmol})$ of 19 in $20 \mathrm{ml}$ of TFA and of $20 \mathrm{mg}$ of $\mathrm{Na}_{2} \mathrm{WO}_{4} \times 2 \mathrm{H}_{2} \mathrm{O}$ in $10 \mathrm{ml}$ of $\mathrm{H}_{2} \mathrm{O}$ were united and the resulting suspension treated with $4 \mathrm{ml}$ of $30 \% \mathrm{H}_{2} \mathrm{O}_{2}$ by dropwise addition. After stirring for 1 day at room temperature was evaporated and the residue stirred with $20 \mathrm{ml}$ of $\mathrm{H}_{2} \mathrm{O}$. The solid was collected and gave after recrystallization from $20 \mathrm{ml}$ of $\mathrm{DMF} / \mathrm{H}_{2} \mathrm{O} 1 / 10.152 \mathrm{~g}(70 \%)$ of yellow crystals of m.p. $>260^{\circ}$ (decomp.). UV $\left(\mathrm{CH}_{3} \mathrm{CN}\right): 245$ (4.18), 354 (4,46). MS : $446\left(\mathrm{M}^{+}\right) .{ }^{1} \mathrm{H}-\mathrm{NMR}$ (D-TFA) : 9.57 (s, 2H, $\mathrm{H}-\mathrm{C}\left(6,6^{\prime}\right)$ ), 3.78 (s, $6 \mathrm{H}, \mathrm{N}-\mathrm{CH}_{3}$ ), 3.69 (s, 6H, N-CH $)$. Anal. calc. for $\mathrm{C}_{16} \mathrm{H}_{14} \mathrm{~N}_{8} \mathrm{O}_{6} \mathrm{SxH}_{2} \mathrm{O}$ (464.3) : $\mathrm{C} 42.25$, H3.52, N24.65; found : C42.22, H3.57, N24.46.

\section{Bis-(1,3-dimethyllumazin-7-yl) (21)}

Analogous to procedure $140.45 \mathrm{~g}(2 \mathrm{mmol})$ of 7 chloro-1,3-dimethyllumazine (18) (17) were heated to $70^{\circ}$ for 1.5 hours. Work-up by extraction was the same and gave after recrystallization of the reaction product from $140 \mathrm{ml}$ of DMF by addition of $7 \mathrm{ml}$ of $\mathrm{H}_{2} \mathrm{O} 0.24 \mathrm{~g}(63 \%)$ of yellowish crystals of m.p. $>350^{\circ}$. UV $\left(\mathrm{CH}_{2} \mathrm{Cl}_{2}\right): 225$ (4.35), 246 (4.54), 382 (4.42), [398 (4.32)]. MS : $382\left(\mathrm{M}^{+}\right) . \quad{ }^{1} \mathrm{H}-\mathrm{NMR}$ (D-TFA) : 9.90 (s, $\left.2 \mathrm{H}, \mathrm{H}-\mathrm{C}\left(6,6^{\prime}\right)\right) ; 4.07$ (s, $\left.6 \mathrm{H}, \mathrm{N}-\mathrm{CH}_{3}\right) ; 3.76(\mathrm{~s}, 6 \mathrm{H}, \mathrm{N}-$ $\mathrm{CH}_{3}$ ). Anal. calc. for $\mathrm{C}_{18} \mathrm{H}_{14} \mathrm{~N}_{8} \mathrm{O}_{4}$ (382.2) : C50.29, H3.69, N29.29; found C49.96, H3.82, N29.20.

\section{Bis-(5,6,7,8-tetrahydro-1,3-dimethyllumazin-7-yl) Dihy- drochloride (22)}

In $20 \mathrm{ml}$ of TFA $30 \mathrm{mg}$ of $\mathrm{PtO}_{2}$ were reduced in a shaking apparatus under hydrogen atmosphere. Then a solution of $0.191 \mathrm{~g}(0.5 \mathrm{mmol})$ of 21 in $20 \mathrm{ml}$ TFA was added and the reduction continued for 8 hours. After 4 hours the theoretical amount of $\mathrm{H}_{2}$ was taken up. The catalyst was filtered off and the filtrate dropwise added to a solution of methanolic $\mathrm{HCl}$. After evaporation the residue was treated with ether, then dissolved in $\mathrm{MeOH}$ and finally added to ether with stirring forming a precipitate. Drying in vacuum yielded $0.127 \mathrm{~g}(66 \%)$ of a colorless powder of m.p.> $310^{\circ}$ (decomp.). UV (pH 1.0) : 205 (4.43); 267 (4.43); (pH 7.0) : [247 (3.86)], 300 (4.26). MS : $390\left(\mathrm{M}^{+}\right) .{ }^{1} \mathrm{H}-$ NMR (D-TFA) : 5.12 (bs, 2H, H-C (7,7')); 4.36+4.12 (dd, $4 \mathrm{H}, \mathrm{H}-\mathrm{C}\left(6,6^{\prime}\right)$ ); 3.77 (s, $\left.6 \mathrm{H}, \mathrm{N}-\mathrm{CH}_{3}\right) ; 3.60$ (s, $6 \mathrm{H}$, $\left.\mathrm{N}-\mathrm{CH}_{3}\right)$ ). Anal. calc. for $\mathrm{C}_{16} \mathrm{H}_{22} \mathrm{~N}_{8} \mathrm{O}_{4} \times 2 \mathrm{HCl} \times 2 \mathrm{H}_{2} \mathrm{O}$ (499.3) : C38.48, H5.65, N22.44; found C38.53, H5.38, N22.32.

Bis-(5-acetyl-5,6,7,8-tetrahydro-1,3-dimethyllumazin-7yl) (23)

Analogous to the preceding procedure $0.191 \mathrm{~g}(0.5$ mmol) of 21 were reduced in TFA. After filtration of the catalyst the filtrate was evaporated to dryness and the residue heated under gentle reflux in $20 \mathrm{ml}$ of $\mathrm{Ac}_{2} \mathrm{O}$ for $30 \mathrm{~min}$. Evaporation and treatment of the remaining solid with acetone yielded $0.167 \mathrm{~g}(76 \%)$ of a colorless powder of m.p. $>330^{\circ}$. UV $(\mathrm{MeOH}): 211$ (4.22), 246 (3.82), 287 (4.24). MS : $474\left(\mathrm{M}^{+}\right) .{ }^{1} \mathrm{H}-\mathrm{NMR}$ (D-TFA) : 5.30 (d, 2H, H-C (6)); 3.83 (s, 6H, N-CH3); 3.57 (s, $\left.6 \mathrm{H}, \mathrm{N}-\mathrm{CH}_{3}\right) ; 3.66$ (s, $2 \mathrm{H}, \mathrm{H}-\mathrm{C}\left(7,7^{\prime}\right)$ ); 3.06 (d, $2 \mathrm{H}, \mathrm{H}-\mathrm{C}\left(6^{\prime}\right)$ ); 2.43 (s, $\left.6 \mathrm{H}, \mathrm{Ac}\right)$. Anal. calc. for $\mathrm{C}_{20} \mathrm{H}_{26}$ $\mathrm{N}_{8} \mathrm{O}_{6} \times 2 \mathrm{H}_{2} \mathrm{O}$ (510.4) : C47.05, H5.92, N21.95; found : C46.88, H5.78, N21.80.

Coupling of 6-chloro-(11) and 7-chloro-1,3-dimethyllumazine (18) to 6, 14 and 21

Analogous to procedure $140.226 \mathrm{~g}(1 \mathrm{mmol})$ of 11 and $0.226 \mathrm{~g}(1 \mathrm{mmol})$ of 18 were reacted at $50^{\circ}$ for 2 hours. Work-up by extraction gave a mixture of three compounds which was separated by preparative silica gel chromatography on plates $(20 \times 20 \times 0.2 \mathrm{~cm})$ in toluene/EtOAc (4/1) to give $60 \mathrm{mg} \mathrm{(16 \% )}$ of 21 (Rf $0.44), 20 \mathrm{mg}(5 \%)$ of $6(\mathrm{Rf} 0.54)$ and $0.115 \mathrm{~g}(30 \%)$ of 14 (Rf 0.70). All three compounds were chromato- 
graphically and spectrophotometrically identical with the authentic materials.

\section{References}

1. Viscontini M. Piraux M. Helv. Chim. Acta 1963, 46, 1537.

2. Pfleiderer W. In : Iwai $\mathrm{K}$, Akino $\mathrm{M}$, Goto $\mathrm{M}$, Iwanami $\mathrm{Y}$, eds. Chemistry and Biology of Pteridines Tokyo, : International Academic Printing Co. 1970, 7.

3. Mager HIX, Berends W. Recueil 1972, 91, 1137.

4. Kobayashi Y, litake Y, Gottlieb R, Pfleiderer W. Acta Cryst. 1977, B33, 2911.

5. Pfleiderer W, Gottlieb R. Heterocycles 1980, 14, 1603.

6. Gottlieb R, Pfleiderer. Liebigs Ann. Chem. 1981, 1451.

7. Kollmannsberger G, Gottlieb R, Pfleiderer W. Ber. Bunsenges. Phys. Chem. 1981, 85, 1148.
8. Vanderesse R, Brunet J, Caubere P. J. Organomet. Chem. 1984, 264, 263.

9. Vanderesse R, Brunet J, Caubere P. J. Organomet. Chem. 1978, 157, 125.

10. Caubere P. Angew. Chem. 1983, 95, 597.

11. Vanderesse R, Loveratz M, Forst Y, Caubere P. Tetrahedron Lett. 1986, 27, 5483.

12. Tiecco M, Testafarri L, Tingoli M, Chianelli D, Montanucci M. Synthesis 1984, 1813.

13. Naumann C, Langhals H. Synthesis 1990, 279.

14. Nasielki J. Synth. Commun. 1991, 21, 901.

15. Pfleiderer W. Liebigs Ann. Chem. 1971, 747, 111.

16. Pfleiderer W. Chem. Ber. 1957, 90, 2582.

17. Steppan H, Hammer J, Baur R, Gottlieb R, Pfleiderer W. Liebigs Ann. Chem. 1982, 2135.

18. Kazimierczuk Z, Pfleiderer W. Chem. Ber. 1979, 112, 1499. 
Pteridines

Vol. 5, 1994, pp. 129-132

\title{
Synthesis of N-(4-propargylaminobenzoyl)-L-glutamates
}

\author{
Michal Kempny, Barbara Rzeszotarska ${ }^{\S}$ and Krzysztof Pawelczak \\ Department of Organic Chemistry, University of Opole, Oleska Str. 48, 45-052 Opole, Poland
}

(Received August 1, 1994)

\section{Summary}

To facilitate the rather labour consuming synthesis of antifolate $\gamma$-oligo-L-glutamates including those with the propargyl group at position $\mathrm{N}^{10}$, two synthons possessing this group, $\alpha$-t-butyl $\gamma$-methyl $N$-(4-propargylaminobenzoyl)-L-glutamate (1) and $\alpha$-t-butyl $N$-(4-propargylaminobenzoyl)-L-glutamate (2) have been elaborated (Scheme 2) and characterized by melting points, elemental analysis, NMR, TLC and HPLC. They are of purity $>98.5 \%$ by the last method.

Key words: $N$-(4-propargylaminobenzoyl)-L-glutamates, $\mathrm{N}^{11}$-propargyl antifolates. ${ }^{1} \mathrm{H}$ NMR spectra, HPLC, Short column chromatography.

\section{Introduction}

A potent thymidylate synthase (EC 2.1.1.45) inhibitor, $N$-[4-[(2-amino-3,4-dihydro-4-oxo-6-quinazolinyl)methyl]prop-2-ynyl-amino]benzoyl--L-glutamic acid (Scheme 1; synonyms : $\mathrm{N}^{11}$-propargyl-5,8-dideazafolic acid, CB 3717, PDDF, ICI 155, 387, NSC 327182 ) (1) continues to be the lead structure in designing and synthesising related compounds, which retain the benficial impact of the $\mathrm{N}^{10}$-propargyl group on binding the enzyme, but at the same time have more desirable biochemical and pharmacological profiles than the parent CB 3717 (2-9). To determine the detailed biological and pharmacological properties of these antifolic analogues indispensable are appropriate investigations of their $\gamma$-conjugates with glutamic acid, g-oligo(glutamic acid)s or another amino $\operatorname{acid}(\mathrm{s})(6,10-13)$. They can be obtained (Scheme 1) according to either of the strategies of peptide chain building $(14)$, convergent $(11,13)$ or step by step $(10,12)$. Both are labour consuming and for both, la-

\footnotetext{
${ }^{8}$ Author to whom correspondence should be addressed. Funding organisation : The Polish State Committee for Scientific Research $(\mathrm{KBN})$; a grant-in-aid.

Abbreviation used : Glu, glutamic acid; $t \mathrm{Bu}, t$-butyl; Me, methyl; $Z$, benzyloxycarbonyl.
}

bour saving synthons of $\mathrm{BC}$ type are desirable. The convergent plan requires compounds $\mathrm{BC}$ with both glutamic acid carboxyl groups protected, each in different manner. In the stepwise strategy, the glutamic acid $\gamma$-carboxyl group should be free. Herein we report on the preparation of $\alpha$-t-butyl $\gamma$-methyl $\mathrm{N}$-(4propargylaminobenzoyl)-L-glutamate (1) and $a$-tbutyl N-(4-propargylaminobenzoyl)-L-glutamate (2) (Scheme 2), some valuable intermediates in the synthesis of $\mathrm{N}^{10}$-propargyl-5,8-dideazafolic acid analogues shown in Scheme 1 as well as of other analogues of $\mathrm{N}^{10}$-propargylfolic acid.

\section{Experimental Part}

General. Purified solvents (Polskie Odczynniki Chemiczne) were stored over drying agents. Organic solutions were dried with anhydrous $\mathrm{Na}_{2} \mathrm{SO}_{4}$. Solvents from them and from fractions after column chromatography were removed in vacuo on a rotatory evaporator at a bath temperature not exceeding $30^{\circ} \mathrm{C}$ unless otherwise indicated. The reactions were monitored and the homogeneity of products was checked by TLC (DC Alufolien Kieselgel 60 No 5553 Merck) in systems: (A) chloroform-methanol-acetic acid (95 $: 5: 3$ ) and (B) chloroform-methanol-conc. ammonia 

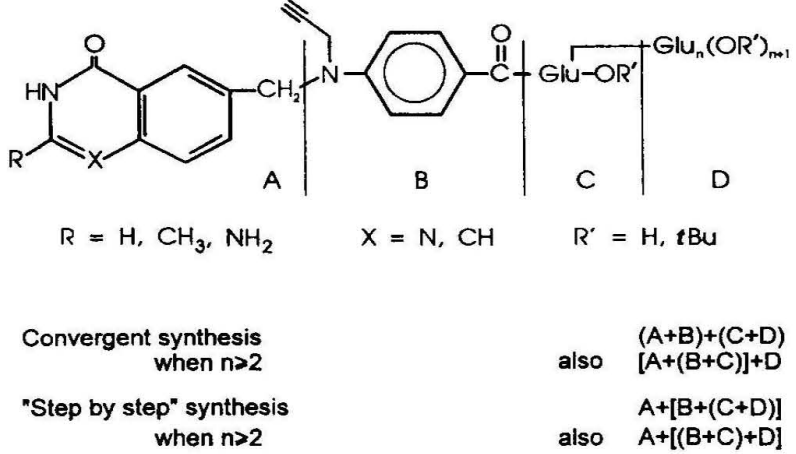

Scheme 1. General structure of $\gamma$-oligo-L-glutamates of $\mathrm{N}^{10}$ propargyl-5,8-dideazafolic acid $\left(\mathrm{R}=\mathrm{NH}_{2}, \quad \mathrm{R}^{\prime}=\mathrm{H}, \mathrm{X}=\mathrm{N}\right.$ and $n=0$ ) and its analogues. Division has been shown into moieties A, B, C and D, Which can be linked according to the convergent or stepwise peptide synthesis strategy.

$(6: 5: 1)$. Spots were visualized with chlorine-KItolidine reagent and ninhydrin. M.ps. were determined on a Boëtius heating block and are given uncorrected. HPLC analyses were performed on a Beckman "System Gold" for Methods Development consisting of a Model 126 programable module, a Model 168 diode array detector operating at $210 \mathrm{~nm}$, a Model $210 \mathrm{~A}$ injection valve with a $5 \mu \mathrm{l}$ loop and a PC386SX (Wearnes) with "System Gold" version 5.1 software for data collection and controller function. Samples, dissolved in acetonitrile, a $150 \times 4.6 \mathrm{~mm}$ Alltima C18 $5 \mu \mathrm{m}$ column, purchases from Alltech and a mobile phase with a flow rate $1 \mathrm{ml} / \mathrm{min}$ were used. Elemental analyses were performed on a Perkin-Elmer analyzer. ${ }^{1} \mathrm{H}$ NMR spectra were taken on a $100 \mathrm{MHz}$ Tesla BS 567 spectrometer in $\mathrm{CD}_{3} \mathrm{COCD}_{3}$ with tetramethylsilan as internal standard.

\section{a-t-butyl $\gamma$-methyl L-glutamate hydrochloride}

Method (A). To stirred dioxane $(250 \mathrm{ml})$ with conc. $\mathrm{H}_{2} \mathrm{SO}_{4}(25 \mathrm{ml})$, cooled to $10^{\circ} \mathrm{C}$, liquid isobuten $(250 \mathrm{ml})$ was poured, the total stirred at $5^{\circ} \mathrm{C}$ for $20 \mathrm{~min}$ and Glu (OMe) (Bachem) (24.2 g, $150 \mathrm{nmol}$ ) introduced. Stirring was continued at $20^{\circ} \mathrm{C}$ for $4 \mathrm{~h}$, the obtained clear solution cooled to $0^{\circ} \mathrm{C}$ was added. The resulted solution was extracted with diethyl ether $(3 \times 200 \mathrm{ml})$. The organic pool was washed with cooled water and cooled brine (200 $\mathrm{ml}$ each). After drying, ether (300 $\mathrm{ml}$ ) was evaporated at a bath temperature not exceeding $10^{\circ} \mathrm{C}, 2 \mathrm{~N}$ etheric $\mathrm{HCl}(50 \mathrm{ml})$ added dropwise with intense stirring and after $20 \mathrm{~min}$ the formed precipitate was filtered off, washed with cooled ether and hexane $(2 \times 100 \mathrm{ml}$ each) and dried in vacuo for $24 \mathrm{~h}$ to give $22.8 \mathrm{~g}$ (60\% yield) of $\mathrm{HCl} . \mathrm{Glu}(\mathrm{OMe})-\mathrm{OtBu}$ of m.p. $131 \sim 132^{\circ} \mathrm{C}$. $R_{f}(B) 0.85$.

Method (B). Through a solution of Z-Glu (OMe)-

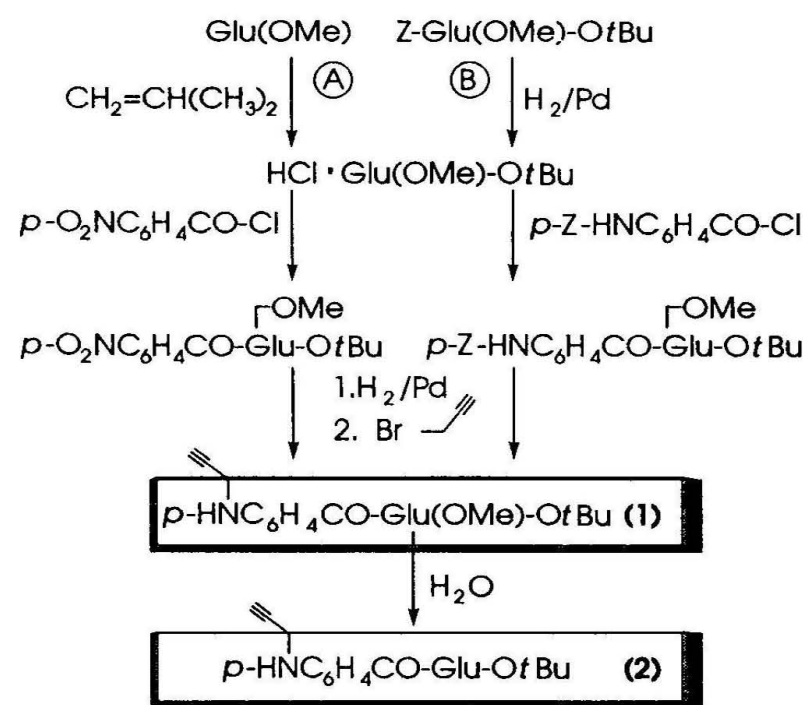

Scheme 2. Synthetic scheme of $\alpha$-t-butyl $\gamma$-methyl N-(p-propargylbenzoyl)-L-glutamate (1) and $\alpha$-t-butyl $N$-(p-propargylbenzoyl)-L-glutamate (2).

OtBu (15) (5.27 g, $15 \mathrm{mmol})$ in methanol (45 ml) with $10 \% \mathrm{Pd} / \mathrm{C}(1.1 \mathrm{~g})$, wetted with ethanol, hydrogen was bubbled for $20 \mathrm{~min}$. The catalyst was filtered off, washed with methanol and the filtrate was concentrated at a bath temperature not exceeding $15^{\circ} \mathrm{C}$ to about $15 \mathrm{ml}$ and cooled to $0^{\circ} \mathrm{C}$. $2 \mathrm{~N}$ Etheric $\mathrm{HCl}$ $(7 \mathrm{ml})$ was added dropwise followed by petroleum ether $(20 \mathrm{ml})$ and after $30 \mathrm{~min}$ the resulted precipitate was filtered off, washed with cooled ether and hexane ( $2 \times 10 \mathrm{ml}$ each) and dried in vacuo for $24 \mathrm{~h}$ to furnish $3.55 \mathrm{~g}$ (93\% yield) of $\mathrm{HCl}$.Glu(OMe)-OtBu of m.p. 129 $\sim 130^{\circ} \mathrm{C} . \operatorname{Rr}(\mathrm{B}) 0.85$.

\section{$\alpha$-t-butyl-r-methyl $\quad N$-(p-benzyloxycarbonylaminobenzo- yl)-L-glutamate}

To a stirred solution of $\mathrm{p}-\mathrm{Z}-\mathrm{NHC}_{6} \mathrm{H}_{4} \mathrm{CO}-\mathrm{Cl}$ (16) (20.35 g, $70 \mathrm{mmol}$ ) and HCl.Glu(OMe)-OtBu (16.70 g, $70 \mathrm{mmol})$ in dioxane $(70 \mathrm{ml})$, cooled to $5^{\circ} \mathrm{C}$, tri(n-butyl)amine $(33.60 \mathrm{ml}, 140 \mathrm{mmol})$ was being added dropwise for $20 \mathrm{~min}$ and stirring was continued at 20 ${ }^{\circ} \mathrm{C}$ for $20 \mathrm{~min}$. Ethyl acetate was added $(750 \mathrm{ml})$, washed with water, $0.1 \mathrm{~N} \mathrm{HCl}$, brine, $0.4 \mathrm{M} \mathrm{K}_{2} \mathrm{CO}_{3}$ and brine $(3 \times 150 \mathrm{ml}$ each), dried and evaporated. The residue, crystallized from $\mathrm{CH}_{2} \mathrm{Cl}_{2}$ /petroleum ether gave the product $(31.25 \mathrm{~g}, 95 \%$ yield $)$ of m.p. 108 $\sim 108.5^{\circ} \mathrm{C}$. Rf(A) 0.50 . HPLC, $0.1 \%$ trifluoroacetic acid : acetonitryl $(30: 70): \mathrm{tR}=3.38 \mathrm{~min} ; 98.9 \% \mathrm{pu}-$ rity. 'H-NMR: 7.95 (d, 2H, Ar2'6'), 7.65 (d, 1H, ArCONH), 7.40 (s, 5H, Ar), 7.30 (bs, $1 \mathrm{H}, \mathrm{NH}$ ), 6.90 (d, $2 \mathrm{H}, \mathrm{Ar} 3{ }^{\prime} 5$ ), 4.85 (s, 2H, $\mathrm{ArCH}_{2}$ ), 4.20 (m, 1H, aCH), $3.60\left(\mathrm{~s}, 3 \mathrm{H}, \mathrm{CH}_{3}\right), 2.50-3.00\left(\mathrm{~m}, 4 \mathrm{H}, \mathrm{CH}_{2}-\mathrm{CH}_{2}\right), \quad 1.45$ (s, $\left.9 \mathrm{H}, \mathrm{C}\left(\mathrm{CH}_{3}\right)_{3}\right)$. Anal. calc. for $\mathrm{C}_{25} \mathrm{H}_{30} \mathrm{~N}_{2} \mathrm{O}_{7}$ (470.2) : $\mathrm{C}$ 
63.80, H 6.43, N 5.96; found: C 64.08, H 6.61, N 6.10 .

$\alpha$-t-butyl $\gamma$-methyl $N$-(p-nitrobenzoyl)-L-glutamate

To a stirred solution of $\mathrm{p}-\mathrm{O}_{2} \mathrm{NC}_{6} \mathrm{H}_{4} \mathrm{CO}-\mathrm{Cl}$ (Aldrich) (1.69 g, $9 \mathrm{mmol}$ ) and $\mathrm{HCl} . \mathrm{Glu}(\mathrm{OMe})-\mathrm{OtBu}(2.28 \mathrm{~g}, 9$ mmol) in dioxane $(9 \mathrm{ml})$, cooled to $5^{\circ} \mathrm{C}$, tri(n-butyl) amine $(4.3 \mathrm{ml}, 18 \mathrm{mmol})$ was being added dropwise for $20 \mathrm{~min}$ and stirring was continued at $20^{\circ} \mathrm{C}$ for 20 min. The same work-up as above furnished a colourless oil (3.13 g, 95\% yield). $\operatorname{Rr}(A) 0.37$.

$\alpha$-t-butyl $\gamma$-methyl $N$-(p-propargylbenzoyl)-L-glutamate (I)

Through a solution of p-Z-NHC $\mathrm{H}_{4} \mathrm{CO}-\mathrm{Glu}(\mathrm{OMe})$ $\mathrm{OtBu}$ or $\mathrm{p}-\mathrm{O}_{2} \mathrm{NC}_{6} \mathrm{H}_{4} \mathrm{CO}-\mathrm{Glu}(\mathrm{OMe})-\mathrm{OtBu}(30 \mathrm{mmol}$ each) in methanol $(120 \mathrm{ml})$ with $10 \% \mathrm{Pd} / \mathrm{C}(20 \%$ weight of a substrate), wetted with ethanol, hydrogen was bubbled for $1.5 \mathrm{~h}$. The catalyst was filtered off, washed with methanol, the filtrate evaporated to an oil, diethyl ether was added and evaporated to give, after drying in vacuo for $12 \mathrm{~h}, \mathrm{p}-\mathrm{H}_{2} \mathrm{NC}_{6} \mathrm{H}_{4} \mathrm{CO}-\mathrm{Glu}$ (OMe)-OtBu (29.7 mmol). This was dissolved in dimethylacetamide $(30 \mathrm{ml})$ and $\mathrm{CaCO}_{3}(45 \mathrm{mmol})$ and a $80 \%$ toluene solution of propargyl bromide (Aldrich) ( $3.6 \mathrm{ml}, 32 \mathrm{mmol}$ ) were introduced. The mixture was stirred in the dark for $120 \mathrm{~h}$. Ethyl acetate was added $(500 \mathrm{ml})$, washed with water $(4 \times 300 \mathrm{ml}), 0.1 \mathrm{M} \mathrm{Na}$ $\mathrm{HCO}_{3}(2 \times 300 \mathrm{ml})$ and brine $(3 \times 200 \mathrm{ml})$, dried and evaporated. The residue, dissolved in $\mathrm{CHCl}_{3}(20 \mathrm{ml})$ was applied to a short column (17) (F $5 \mathrm{~cm}$, silicagel Merck No 7736, $300 \mathrm{~g}$ ) and eluted with chloroform of increasing amount of ethyl acetate from $1 \%$ to $6 \%$ $(6 \times 250 \mathrm{ml})$. The appropriate fractions were evaporated to give $1\left(6.37 \mathrm{~g}, 56 \%\right.$ yield). m.p. $131-133^{\circ} \mathrm{C}$. $\mathrm{R}_{\mathrm{f}}$ (A) 0.66 . HPLC, $0.1 \%$ trifluoroacetic acid : acetonitryl $(50: 50): \mathrm{tR}=5.85 \mathrm{~min} ; 99.0 \%$ purity. ${ }^{1} \mathrm{H}-\mathrm{NMR}$ : 7.90 (d, 2H, AR2'6'), 7.170 (d, 1H, ArCONH), 6.85 (d, $\left.2 \mathrm{H}, \operatorname{Ar3}{ }^{\prime}{ }^{\prime}\right), 6.00(\mathrm{t}, 1 \mathrm{H}, \mathrm{NH}), 4.60(\mathrm{~m}, 1 \mathrm{H}, \mathrm{aCH}), 4.10$ (d, 2H, NCH2), 3.65 (s, 3H, CH3), $3.00(\mathrm{t}, 1 \mathrm{H},>\mathrm{CH})$, 2.05-2.60 (m, 4H, $\left.\mathrm{CH}_{2}-\mathrm{CH}_{2}\right), 1.50\left(\mathrm{~s}, 9 \mathrm{H}, \mathrm{C}\left(\mathrm{CH}_{3}\right)_{3}\right)$. Anal. calc. for $\mathrm{C}_{20} \mathrm{H}_{26} \mathrm{~N}_{2} \mathrm{O}_{5}$ (374.2) : C 64.14, H 7.00, N7.48; found : C64.54, H7.36, N7.39.

\section{a-t-butyl N-(p-propargylbenzoyl)-L-glutamate (2)}

To a stirred solution of $\mathbf{1}(6.37 \mathrm{~g}, 17 \mathrm{mmol})$ in acetone $(35 \mathrm{ml})$ at $30^{\circ} \mathrm{C}, 1 \mathrm{~N} \mathrm{NaOH}(20.5 \mathrm{ml})$ was added. Stirring was continued at $30^{\circ} \mathrm{C}$ for $20 \mathrm{~min}, 1 \mathrm{~N}$ $\mathrm{HCl}(20.5 \mathrm{ml})$ added and acetone evaporated. Water was added and extracted with ethyl acetate $(2 \times 100$ $\mathrm{ml})$. The organic pool was washed with water and brine $(3 \times 50 \mathrm{ml}$ each $)$, dried, evaporated and crys- tallized from $\mathrm{H}_{2} \mathrm{Cl}_{2}$ /petroleum ether to furnish 2 (4.90 g, $80 \%$ yield) of m.p. $141 \sim 142^{\circ} \mathrm{C} \operatorname{Rr}(A) 0.37$. HPLC, $0.1 \%$ trifluoroacetic acid : acetonitryl $(50: 50): \mathrm{tR}=$ $3.05 \mathrm{~min}$; $98.5 \%$ purity. 'H-NMR: 7.85 (d, 2H, Ar2'6'), 7.60 (d, 'H, ArCONH), 6.80 (d, 2H, Ar3'5'), 6.10 (bs, $1 \mathrm{H}, \mathrm{NH}), 4.65(\mathrm{~m}, 1 \mathrm{H}, \mathrm{aCH}), 4.05$ (d, 2H, NCH2), 2.95 (t, $1 \mathrm{H}, \equiv \mathrm{CH}), 2.00 \sim 2.75\left(\mathrm{~m}, 4 \mathrm{H}, \mathrm{CH}_{2}-\mathrm{CH}_{2}\right), 1.50$ (s, $\left.9 \mathrm{H}, \mathrm{C}\left(\mathrm{CH}_{3}\right)_{3}\right)$. Anal. calc. for $\mathrm{C}_{19} \mathrm{H}_{24} \mathrm{~N}_{2} \mathrm{O}_{5}$ (360.2) : C64.30, H 6.72, N7.78; found : C63.40, H7.15, N7.87.

\section{Results and Discussion}

$\alpha$-t-Butyl $\gamma$-methyl N-(p-propargylbenzoyl)-L-glutamate (1) can be obtained in two ways, A or B (Scheme 2). The advantage of the former are commercial substrates. Drawbacks are (i) cool edulcorations in preparing $\mathrm{Glu}(\mathrm{OMe})-\mathrm{OtBu}$ due to numerous side-reactions and (ii) the product of p-nitrobenzoylation, $\mathrm{p}-\mathrm{O}_{2} \mathrm{NC}_{6} \mathrm{H}_{4} \mathrm{CO}-\mathrm{Glu}$ (OMe)-OtBu being an oil. Way $\mathrm{B}$ is very easy, fast and highyielding (83\% of p-Z-HNC ${ }_{6} \mathrm{H}_{4} \mathrm{CO}-\mathrm{Glu}(\mathrm{OMe})-\mathrm{OtBu}$ overall), but fullyblocked substrates are used, the synthesis of which has however been well-elaborated $(15,16)$. We eventually recommend as the most practical Glu(OMe) and to acylate the diester with $\mathrm{p}-\mathrm{Z}-\mathrm{HNC}_{6} \mathrm{H}_{4} \mathrm{COCl}$. The two steps should be best performed one by one, because as $\mathrm{Glu}(\mathrm{OMe})-\mathrm{OtBu}$, also its hydrochloride is not stable. After one week of standing the latter in a refrigerator, some decomposition has already been visible by TLC (system B). Hydrogenation of both p-nitrobenzoyl- and p-benzyloxycarbonyl-glutamate is very fast and poses no problem. Propargylation proceeds with by-formation of the dialkyl derivative and the post-reaction mixture requires to be chromatographed. L-Glutamate $\mathbf{1}$ is easily saponified to give $\alpha$-t-butyl N-(p-propargylbenzoyl)-L-glutamate (2). Compounds 1 and $\mathbf{2}$ have been characterized by melting points, elemental analysis, NMR. TLC and HPLC. They are of purity $>98.5 \%$ by the last method. The application of $\mathbf{2}$ for the convenient synthesis of a series of $\mathrm{t}$-butyl $\mathrm{N}$-(4-propargylaminobenzoyl)-g-oligo (L-glutamate)s will be published in a forthcoming paper.

\section{Acknowledgement}

Financial support of this work from the Polish State Committee for Scientific Research within a grant-in aid deserved our grateful thanks.

\section{References}

1. Jones TR, Calvert AH, Jackman AL, Brown SJ, Jones M, Harrap KR. A potent antitumor quinazoline inhibitor of thymidylate synthase: synthesis, biological properties and 
therapeutic results in mice. Eur J Cancer 1981; 17: 11-19.

2. Jones TR, Thornton JT, Flinn A., Jackman AL, Newell RD, Calvert AH. Quinazoline antifolates inhibiting thymidylate synthase: 2-desamino der:vatives with enhanced solubility and potency. J. Med Chem 1989; 32: 847-852.

3. Hughes LR, Jackman AL, Oldfield J. et al. Quinazoline antifolate thymidylate synthase inhibitors: alkyl, substituted alkyl and aryl substituents in the C2 postition. J Med Chem 1990; 33: 3060-3067.

4. Jackman AL, Taylor GA, O'Connor BM, Bishop JA, Moran RG, Calvert AH. Activity of the thymidylate synthase inhibitor 2-desamino- $\mathrm{N}^{10}$-propargyl-5,8-dideazafolic acid and related compounds in murine (L1210) and human (WIL2) systems in vitro and in vivo. Cancer Res 1990; 50: 5212-5218.

5. Shou Wen Li, Nair MG, Edwards DM, et al. Folate Analogues. 35 Synthesis and biological evaluation of 1-deaza, 3-deaza and bridge-elongated analogues of $\mathrm{N}^{10}$-propargyl5,8-dideazafolic acid. J Med Chem 1991; 34: 2746-2754.

6. Jackman AL, Bisset GMF, Jodrell DI, et al. g-Linked dipeptide analogues of 2-desamino-2-methyl- ${ }^{10}$-propargyl5,8-dideazafolate as antitumour agents. In: Ayling JE, Nair MG, Baugh CM eds. Chemistry and biology of pteridines and folates. New York-London: Plenum Press, 1993; 579 -584 .

7. Boyle FT, Matusiak ZS, Hughes LR, et al. Substituted 2desamino-2-methyl-quinazolinones. A series of novel antitumour agents. In: Ayling Je, Nair MG, Baugh CM eds. Chemistry and biology of pteridines and folates. New York-London: Plenum Press, 1993; 585-588.

8. Stephens TC, Smith MN, Waterman SE, McCloskey ML, Jackman AL, Boyle FT. Use of murine L5178Y lymphoma thymidine kinase mutants for in vitro and in vitro antitumour efficacy evaluation of novel thymidylate synthase inhibitors. In: Ayling JE, Nair MG, Baugh CM eds. Chemistry and biology of pteridines and folates. New YorkLondon: Plenum Press, 1993; 589-592.

9. Kimbell R, Jackman AL, Boyle FT, Hardcastle A, Aherne $\mathrm{W}$. The duration of the inhibition of thymidylate synthase in intact L1210 cells exposed to two different classes of quinazoline analogues. In: Ayling JE, Nair MG, Baugh CM eds. Chemistry and biology of pteridines and folates. New York-London: Plenum Press, 1993; 597-600.

10. Pawelczak K, Jones TR, Kempny M. et al. Quinazoline anti-folates-(L- $\gamma$-glutamyl)conjugates of $\mathrm{N}^{10}$-propargyl-5,8dideazafolic acid and their enzyme inhibition. J. Med Chem 1989; 32: 160-165 and references cited therein.

11. Bisset GMF, Pawelczak K, Jackman AL, Calvert AH. Syntheses and thymidylate synthase inhibitory activity of the poly- $\gamma$-glutamyl conjugates of $\mathrm{N}$-[5-[N-(3,4-dihydro-2-methyl-4-oxoquinazolin-6-ylmethyl)- $\mathrm{N}$-methylamino]-2-thenoyl-L-glutamic acid (ICI D1694) and other quinazoline antifolates. J Med Chem 1992; 35: 859-866 and references cited therein.

12. Pawelczak K, Kempny M. Bisset G, Jackman AL. Antifolate conjugates containing $\gamma$-aminobutyric acid in poly- $\gamma$-glutamyl chain. Synthesis, enzyme binding, and cell growth inhibition. In: Blau N, Curtius HC, Levine R, Yim J eds. Pteridines and related biogenic amines and folates 1992. Seoul: Hanrim Publishing Co, 1992; 293-304.

13. Bavetsias V, Jackman AL, Thornton TJ, Pawelczak K, Boyle TF, Bisset GMF. Quinazoline antifolates inhibiting thymidylate synthase: synthesis of $\gamma$-linked peptide and amide analogues of 2-desamino-2-methyl- $\mathrm{N}^{10}$-propargyl-5,8-dideazafolic acid (ICI 198583). In: Ayling JE, Nair MG, Baugh $\mathrm{CM}$ eds. Chemistry and biology of pteridines and folates. New York-London: Plenum Press, 1993; 593-596.

14. Bodanszky M. Principles of peptide synthesis. Berlin-Heidelberg: Springer-Verlag, 1984; 202-217.

15. Pawelczak K, Krzyzanowski L, Rzeszotarska B. Improved synthesis of some $\alpha$-esters of $\mathrm{N}$-protected glutamic acid. Org. Prep. Proced. Int. 1985; 17, 416-419.

16. Krzyzanowski L, Rzeszotarska B. Synthesis of N-(p-carbobenzoxyaminobenzoyl)-L-glutamic acid a-benzyl ester. Org. Prep. Proced. Int. 1985; 17, 83-89.

17. Hunt BJ, Rigby W. Short column chromatography. Chem. \& Ind. 1967; 1868-1869. 
Pteridines

Vol. 5, 1994, pp. 133-135

\title{
Serum Neopterin and Angiotensin-converting Enzyme in Cancer Patients
}

\author{
Bohuslav Melichar ${ }^{1}$, Pavel Jandik², Jaroslava Vávrová3, Jindriska Mergancová2, \\ Eva Maliřová, Zbyněk Vobořil ${ }^{2}$
}

'Second Department of Internal Medicine and Departments of ${ }^{2}$ Surgery, ${ }^{3} \mathrm{Clinical}$ Chemistry and ${ }^{4}$ Nuclear Medicine, Charles University Medical School, Hradec Králové, Czech Republic

(Received June 14, 1994)

\begin{abstract}
Summary
An elevation of serum angiotensin-converting enzyme (ACE) has been reported in some disorders associated with immune activation, e.g. sarcoidosis, HIV infection or ulcerative colitis. Both endothelial cells and macrophages are thought to be the possible source of increased ACE levels. We have investigated serum $\mathrm{ACE}$ and neopterin, an indicator of macrophage activation, in 23 patients with solid tumors as well as in 8 controls. Similar ACE levels have been observed in the cancer patients and the controls $(2.6 \pm 2.1$ vs $3.4 \pm$ $1.1 \mu \mathrm{kat} / 1$, while neopterin has been significantly higher in the cancer patients $(15.4 \pm 12.6 \mathrm{vs} 7.2 \pm 2.2 \mathrm{nmol} / \mathrm{l}$, $\mathrm{P}<0.02$ ). No correlation has been observed between serum ACE and neopterin. We conclude that an elevation of ACE is not present in cancer patients. Macrophage activation in cancer is not accompanied by increased ACE release.
\end{abstract}

Key words: Angiotensin-converting enzyme, Cancer, Neopterin.

\section{Introduction}

Angiotensin-converting enzyme (ACE) is produced mainly by endothelial cells and plays a key role in regulating the metabolism of vasoactive peptides, i.e. the conversion of angiotensin I to angiotensin II and inactivation of bradykinin (1). ACE production was also demonstrated in macrophages and an increase of serum ACE levels resulting from macrophage activation has been associated with sarcoidosis (2). More recently, an increase in serum ACE has been also reported in patients with HIV infection and ulcerative colitis $(3,4)$, but the cellular source of $\mathrm{ACE}$ in these disorders remains to be determined.

Macrophage activation in many clinical situations, including the mentioned disorders, has been associated with a rise in serum and urine neopterin $(5$, $6,7,8)$. Increased neopterin production in these conditions is known to result mainly from the action of interferon-gamma, a cytokine released by T-lym-

${ }_{\S}^{\S}$ Author to whom correspondence should be addressed. phocytes (9), on macrophages, and is now widely used to assess immune activation (5). Elevated urine and serum neopterin levels have been described in many different tumors $(5,10,11,12)$, reflecting the macrophage activation induced by interferon-gamma.

The aim of the present study was to determine whether the rise in serum neopterin in cancer patients is accompanied by increased serum ACE levels.

\section{Material and Methods}

\section{Patients}

Twenty-three previously untreated cancer patients, aged $64 \pm 10(42-77)$ years, were included in the study. Eight patients presented with colorectal cancer, 5 patients had gastric cancer, 4 patients had breast cancer, 2 patients had thyroid cancer, 2 patients had cancer of the esophagus and one patient each had cancer of the pancreas and gastric leiomyosarcoma. Eight subjects, aged $58 \pm 11$ years, presenting for elected operation for inguinal hernia 
served as controls.

In all the studied subjects serum sample was taken before any operative treatment and stored in aliquotes at $-50^{\circ} \mathrm{C}$.

\section{Neopterin determination}

Serum neopterin was determined using a RIA kit (generously provided by Henning, Berlin, Germany) as described (13).

\section{ACE measurement}

ACE was measured by a colorimetric method (14). Fifty $\mu \mathrm{l}$ of the serum sample was incubated with $100 \mu \mathrm{l} 20.5 \mathrm{mmol} / \mathrm{l}$ hippuryl-glycyl-glycine (Sigma, St. Louis, USA) at $37^{\circ} \mathrm{C}$. After 30 minutes, $100 \mu \mathrm{l} 0.33$ $\mathrm{mol} / \mathrm{l}$ sodium tungstate (Lachema, Brno, Czech Republic) and $100 \mu \mathrm{l}$ of $0.33 \mathrm{~mol} / \mathrm{l}$ sulfuric acid (Lachema) were added. After mixing, $1000 \mu \mathrm{l}$ of distilled water was added. The solution was then centrifuged ( $2000 \times \mathrm{g}$ for 10 minutes), and $750 \mu \mathrm{l}$ of the supernatant was incubated with $50 \mu \mathrm{l}$ of $0.1 \mathrm{mmol} / 12,4$, 6-trinitrobenzene sulfonic acid (Sigma) and $1000 \mu$ l of borate buffer, $\mathrm{pH}=9.6$, (Lachema) at room temperature. After 30 minutes the absorbance was read at $405 \mathrm{~nm}$. A standard curve was constructed using glycyl-glycine (Sigma).

\section{Statistical analysis}

The significance of differences was assessed using the Mann-Whitney $\mathrm{U}$ test. The correlation was studied by Spearman rank correlation coefficient. The decision on significance was based on $p=0.05$ significance level.

\section{Results}

Serum neopterin was significantly higher in the cancer patients compared to controls (15.4 \pm 12.6 , range $4.7 \sim 60.6$ vs $7.2 \pm 2.2$, range $5 \sim 10.3 \mathrm{nmol} / \mathrm{l}$, $\mathrm{p}<0.02$ ). On the other hand, ACE activity has not been significantly different $(2.6 \pm 2.1$, range $0.2 \sim 8.7$ vs $3.4 \pm 1.1$, range $1.6 \sim 5.4 \mu \mathrm{kat} / \mathrm{l}$ for cancer patients and controls, respectively). No correlation could be observed between serum neopterin and ACE levels (Figure 1). Only 3 out of 23 patients had ACE activity higher than the normal range, defined as the mean of the controls +2 standart deviations.

\section{Discussion}

As expected from previous studies $(5,10,11,12)$,

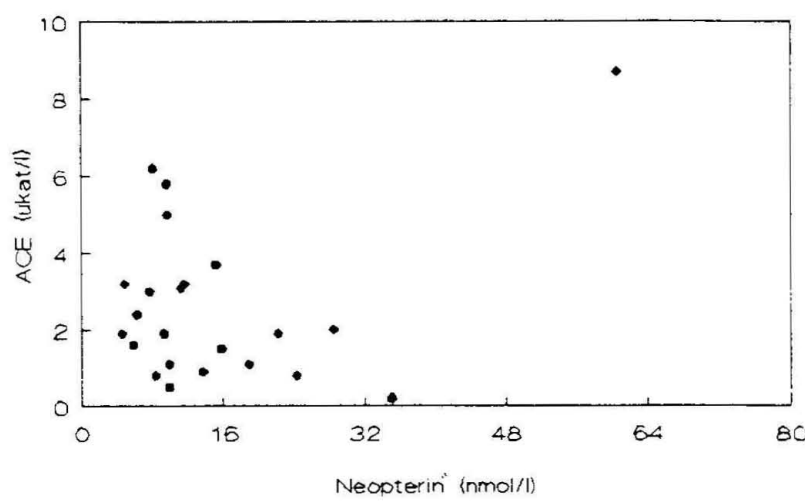

Figure 1. Serum neopterin and ACE in cancer patients ( $\mathrm{rs}=$ -0.1869 , not significant).

serum neopterin was significantly higher in cancer patients. On the contrary, ACE was not elevated.

$\mathrm{ACE}$ is an established marker in sarcoidosis $(1,2)$. Besides this disease, an increase in ACE was reported in a variety of disorders, including HIV infection (3), ulcerative colitis (4), diabetic angiopathy (15) and chronic fatigue syndrome (16). An increase in ACE activity could be also produced in experimental inflammation (17). While in sarcoidosis ACE is thought to be produced by macrophages (1), the cellular source in other mentioned conditions has not yet been unequivocally identified.

Neopterin is an established index of macrophage activation (5). Our results indicate that macrophage activation in cancer patients is not associated with increased serum ACE levels. ACE appears to be elevated only in a small portion of cancer patients.

In conclusion, serum ACE does not seems to be elevated in cancer patients. Macrophage activation in cancer patients, as reflected by increased serum neopterin, is not accompanied by similar rise in ACE. Increased ACE production by macrophages appears to be peculiar to some conditions, notably sarcoidosis, while an elevation in serum ACE in other disorders might come from endothelial cells, but increased $\mathrm{ACE}$, unlike neopterin, does not seem to be a universal marker of macrophage activation.

\section{References}

1. Studdy PR, Lapworth R, Bird R. Angiotensin-converting enzyme and its clinical significance-a review. J. Clin Pathol 1983, 36, 938-947.

2. Lieberman J. Elevation of serum angiotensin-convertingenzyme (ACE) level in sarcoidosis. Am. J. Med 1975, 59, 365-372.

3. Quelletter DR, Kelly JW, Anders GT. Serum angiotensinconverting enzyme level is elevated in patients with human immunodeficiency virus infection. Arch Intern Med 1992, 
$152,321-324$.

4. Letizia C, D Ambrosio, C, Agostini D, Corsi A, Boirivant M, Pallone F, Scavo D. Serum angiotensin converting enzyme activity in Crohn's disease and ulcerative colitis. Ital. J. Gastroenterol 1993, 25, 23-25.

5. Wachter H, Fuchs D, Hausen A, Reibnegger G, Werner ER. Neopterin as marker for activation of cellular immunity : Immunologic basis and clinical application. Adv Clin Chem 1989, 27, 81-141.

†. Fuchs D, Jäger H, Popescu M, Reibnegger G, Werner ER, Dierich MP, Kaboth W, Tilz GP, Wachter H. Immune activation markers to predict AIDS and survival in HIV-1 seropositives. Immunol Lett 1990, 26, 75-80.

7. Fuchs D, Hausen A, Reibnegger G, Werner ER, Dierich MP, Wachter H. Neopterin as a marker for activated cellmediated immunity : Application in HIV infection. Immunol Today 1988, 9, 150-155.

8. Niederwieser D, Fuchs D, Hausen A, Judmaier G, Reibnegger G, Wachter H, Huber C. Neopterin as a new biochemical marker in the clinical assessment of ulcerative colitis. Immunobiol 1985, 170, 320-326.

- Huber C, Batchelor R, Fuchs D, Hausen A, Lang A, Niederwieser D, Reibnegger G, Swetly P, Troppmair J, Wachter $\mathrm{H}$. Immune response-associated production of neopterin. Release from macrophages primarily under control of interferon-gamma. J. Exp. Med. 1984, 160, 310-316.

$\therefore$ Reibnegger G, Fuchs D, Fuith LC, Hausen A, Werner ER, Werner-Felmayer G, Wachter H. Neopterin as a marker for activated cell-mediated immunity : Application in malignant disease. Cancer Detect Prev. 1991, 15, 483-490.
11. Reibnegger G, Bichler A, Dapunt O, Fuchs D, Fuith LC, Hausen A, Hetzel H, Lutz H, Werner ER, Wachter H. Neopterin as a prognostic indicator in patients with carcinoma of the uterine cervix. Cancer Res. 1986, 46, 950-955.

12. Reibnegger G, Hetzel H, Fuchs D, Fuith LC, Hausen A, Werner ER, Wachter H. Clinical significance of neopterin for prognosis and follow-up in ovarian cancer, Cancer. Res. 1987, 47, 4977-4981.

13. Werner ER, Bichler A, Daxenbichler G, Fuchs D, Fuith LC, Hausen A, Hetzel H, Reibnegger G, Wachter H. Determination of neopterin in serum and urine. Clin. Chem. 1987, 33, 62-66.

14. Neels, H M, van Sande, ME, Scharpé, S.L. Sensitive colorimetric assay for angiotensin converting enzyme in serum. Clin. Chem. 1983, 29, 1399-1403.

15. Feman SS, Mericle RA, Reed GW, May JM, Workman RJ. Serum angiotensin converting enzyme in diabetic patients. Am. J. Med. Sci. 1993, 305, 280-284.

16. Liebermann, J. Bell DS. Serum angiotensin-converting enzyme as a marker of the chronic fatigue-immune dysfunction syndrome : a comparison to serum angiotensinconverting enzyme in sarcoidosis. Am. J. Med. 1993, 95, 407-412.

17. Schrier DJ, Rifani LM, Katzenstein AL. Roe of angiotensin-converting enzyme in Bacille Calmette-Guerin-induced granulomatous inflammation J. Clin. Invest. 1982, 69, 651-657.

Dedicated to Professor Dr. Helmut Wachter on occasion of his 65 th birthday. 
Pteridines

Vol. 5, 1994, pp. 136-138

\title{
Immune Activation and HIV-1 Viraemia in an Asymptomatic Paediatric Patient
}

\author{
D. Zaknun, J. Neugebauer, B. Soelder, M.P. Dierich\#, H. Wachter* and D. Fuchs*§ \\ Department of Paediatrics, "Institute for Hygiene and *Institute for Medical Chemistry and Biochemistry, \\ University of Innsbruck and ${ }^{\# *}$ Ludwig Boltzmann Institute for AIDS-Research, A-6020 Innsbruck, Austria.
}

(Received June 20, 1994)

\begin{abstract}
Summary
Immune stimulation due to secondary infection may enhance HIV replication and viraemia, since cellular activation of CD4+ T-cells is required for viral replication. We describe a case of an 18 months old child, exposed intrauterinely to human immunodeficiency virus type 1 (HIV-1). During a period of various infections, which was followed by transient viraemia, decrease of CD4 + T-lymphocytes and increase of neopterin concentrations was registered. Disease progression may have occured due to activation of latent HIV-1 in CD4+ T-lymphocytes/macrophages by secondary infections.
\end{abstract}

Key words: Immune activation, Human immunodeficienjcy virus, Neopterin

\section{Introduction}

The outpatient clinic of the paediatric university hospital in Innsbruck, Austria, cares for 11 children infected with human immunodeficienjcy virus type 1 (HIV-1) aged between 18 months and 16 years. Seven of them were infected by vertical transmission and four received contaminated blood products before 1985 when blood donations have not been tested for HIV antibodies and neopterin concentrations.

HIV-1 infects not only CD4 + T-lymphocytes, but also cells of the monocyte/macrophage lineage expressing the CD4 surface molecule (1). It has been assumed that immune stimulation due to secondary infections may trigger viral replication $(2,3)$, which results in viraemia and death of $\mathrm{CD} 4+\mathrm{T}$-lymphocytes.

Antigen-stimulated T-lymphocytes produce high amounts of interferon- $\gamma$, which is the main inducer of neopterin release from human macrophages in vitro. Neopterin has been shown to be a sensitive mar-

\footnotetext{
${ }^{8}$ Author to whom correspondence should be addressed.
}

ker for activation of cell mediated immunity (4) also in vivo. The majority of individuals with HIV-1 infection shows increased levels of neopterin, this is true even in early stages of infection. CD4 $+\mathrm{T}$-cell counts and neopterin levels usually correlate well, however, both parameters have been shown to jointly predict disease progression in adults $(5,6,7)$ and in children $(8,9)$.

Changes of CD4 + T-cell counts are less marked in peadiatric patients and decline of $\mathrm{CD} 4+\mathrm{T}$-lymphocytes is less significantly correlated with disease progression (9), which contrasts the observations made in adult patients. Although HIV-1 p24 antigenaemia is associated with disease progression $(7,10)$, p24 antigenaemia is not only rare in asymptomatic adults but also in children.

\section{Case Report}

The course of HIV-1 infection in an 18 months old female infant developing viraemia during periods of various childhood infections is described. Being exposed to HIV-1 during pregnancy, the child was spon- 


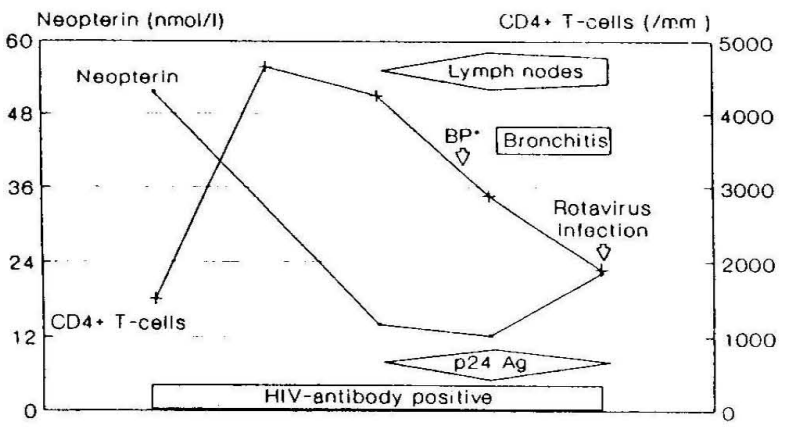

-Bacterial pharyngltis

Figure 1. Course of CD4 + T-cell counts, neopterin and HIV-1 -p24 antigen in a child with HIV-1 infection during episodes of secondary infections.

taneously delivered without further complications. Pregnancy was complicated by daily Methadon administration by the HIV-1-seropositive mother within a rehabilitation (anti-drug treatment) program. The newborn showed signs of withdrawal at the third day of life. In the child HIV-1-antibodies have been found from begin to the end of evaluation. HIV-1 nucleic acid was detected by polymerase chain reaction (PCR).

No clinical complications were registered throughout the first year of life. Infancy was normal regarding nutrition, neurological and cognitive development. The child has been undergoing periodic clincal evaluations for 18 months. Blood was screened ior concentrations of neopterin, a sensitive indicator of immune activation (radioimmunoassay, Henning, Berlin, Germany), for p24 antigen (Abbott, Chicago, IL) and the CD4 + T-lymphocyte count.

At the age of 14 months the child developed severe bacterial pharyngitis associated with fever $\left(39^{\circ} \mathrm{C}\right)$. Oral amoxicilline treatment was able to improve her condition for a period of two weeks only, thereafter the child contracted severe viral bronchitis with heavy cough. When the child recovered from that, she developed enterovirus infection only one month later. While there were no signs of disease progression during the first year of life, the infant developed generalised lymphadenopathy, a remarkable decline in $\mathrm{CD} 4+\mathrm{T}$-lymphocytes and viraemia as was documented by $\mathrm{p} 24$ antigenaemia.

Neopterin levels constantly decreased during the first year of live, but increased significantly after the enteroviral infection (Figure 1). After complete recovery from viral enteritis, disappearance of both the generalised lymphadenopathy and HIV-1 p24 antigenaemia was also documented. However, neopterin levels remained increased compared to the normal range of healthy children within this age group. Con- centrations of beta-2-microglobulin, another valid predictor of progression to AIDS in HIV-1 seropositives, behaved similar to neopterin changes, starting with an increased level, which was followed by a decline and a further rise after secondary infections became manifest (details not shown).

\section{Discussion}

Surrogate markers as neopterin and beta-2-microglobulin are well correlated with stage of HIV-1 infection in adult $(5,6,7)$ and paediatric patients $(8,9,11$, 12 ). Usually there exists a significant inverse correlation between neopterin levels and CD4 + T-cell counts in adult HIV-1 seropositive patients. In the present case we found increasing levels of serum neopterin associated with decreasing $\mathrm{CD} 4+\mathrm{T}$-cell counts. As a whole, neopterin levels appeared to parallel changes of $\mathrm{CD} 4+\mathrm{T}$-cell counts in a mirrorimage fashion (Figure 1). Most probably immune stimmulation induced by a secondary antigen was involved to accelerate the course of HIV-1 infection from an asymptomatic infection to one with detectable HIV-1 antigen. Due to secondary antigenic stimulation, activated lymphocytes may have triggered HIV-1 replication and disease progression. Enhanced production of neopterin in the child reflects this biological background and supports the view that activation of immune cells was related to disease progression. Similarly, general lymphadenopathy was most prominent during phases of viraemia which was reflected by detectable p24 serum antigen. Based on our observation we postulate that immune activation stimulated multiplication and spread of HIV-1 in the infected child.

\section{Acknowledgement}

This work was financially supported by the Austrian Ministry for Science and Research "Sektion Forschung".

\section{References}

1. Gartner S, Markovits P, Markovits DM, Kaplan MH, Gallo $\mathrm{RC}$, Popovic M. The role of mononuclear phagocytes in HTLV III/LAV infection. Science 1986, 233, 215-219.

2. Fuch D, Hausen A, Hengster P, Reibnegger G, Schulz T, Werner ER, Dierich MP, Wachter H. In vivo activation of CD4 + cells in AIDS. Science 1987, 235, 35.

3. Ho. D. HIV-1 viraemia and influenza, Lancet 1992, 339, 1549.

4. Fuchs D, Hausen A, Reibnegger G, Werner ER, Dierich MP, Wachter H. Neopterin as a marker for activated cellmediated immunity : application in HIV infection. Immunol 
Today $1988,9,150-155$.

5. Krämer A, Wiktor SZ, Fuchs D, Milstein S, Gail MH, Yellin FJ, Biggar RJ, Wachter H, Kaufman S, Blattner WA, Goedert JJ. Neopterin : A predictive marker of acquired immune deficiency syndrome virus infection. J. Aquir Immune Defic Syndr 1989, 2, 291-296.

6. Fuchs D, Spira TJ, Hausen A, Reibnegger G, Werner ER, Werner-Felmayer G, Wachter $\mathrm{H}$. Neopterin as a predictive marker for disease progression in human immunodeficiency virus type 1 infection Clin. Chem. 1989, 35, 1571-1814.

7. Fahey JL, Taylor JMG, Detels R, Hofmann B, Melmed R, Nishanian P, Giorgi JV. The prognostic value of cellular and serologic markers in infection with human immunodeficiency virus type 1. New Engl J. Med. 1990, 22, 166172.

8. Cham M, Campos JM, Josephs S, Rifai N. Beta-2-microglobulin and neopterin:predictive markers for human immunodeficiency virus type 1 infection in children ? J. Clin Microbiol 1990, 28, 2215-2219.

9. Ellaurie M, Calvelli T, Rubinstein A. Neopterin concent- rations in pediatric human immunodeficienjcy virus infection as predictor of disease activity. Pediatr Infect Dis. J. 1992, 11, 286-289.

10. Moss AR, Bacchetti P, Osmond D, Krampf W, Chaisson SE, Stites D, Wilber J, Allain JP, Carlson J. Seropositivity for HIV and the development of AIDS or AIDS related condition : three year follow up of the San Francisco General Hospital cohort. Brit Med. J. 1988, 296, 745-750.

11. Zaknun D, Di Franco M, Oswald HP, Zaknun J, Mayersbach P, Vuja E, Wachter H, Fuchs D. Association between neopterin and beta-2-microglobulin levels and HIV status in Romanian orphanage children. Wiener Klin Wschr 1993, 105, 284-288.

12. Di Franco M, Zaknun D, Zaknun J, Vuja E, Oswald HP, Mayersbach P, Hunter D, Toesteson TD, Trichopoulos D, Schmitzberger R, Schönitzer D, Wachter H, Fuchs D. J. A prospective study of the association of serum neopterin, $\beta_{2}$-microglobulin, and hepatitis B surface antigenemia with death in infants and children with HIV-1 disease. Acquir Immune Defic Syndr 1994, 1079-1085. 


\title{
Relationship among Serum hsp65 Antibodies, Neopterin, Autoantibodies and Atherosclerosis
}

\author{
Qingbo Xu, ${ }^{\#}$ Georg Wick, ${ }^{\dagger}$ Helmut Wachter $^{\dagger \dagger}$ and Gilbert Reibnegger* \\ \#Institute for Biomedical Aging Research, Austrian Academy of Sciences, Rennweg 10, \\ A-6020 Innsbruck, Austria \\ ${ }^{\dagger}$ Institute for General and Experimental Pathology, University of Innsbruck \\ ${ }^{++}$Institute for Medical Chemistry and Biochemistry, University of Innsbruck, Fritz Pregl Straße 3, \\ A-6020 Innsbruck, Austria \\ *Medizinisch-Chemisches Institut und Pregl Laboratorium, Harrachgasse 21, A-8010 Graz, Austria
}

(Received June 20, 1994)

\begin{abstract}
Summary
A statistical reinvestigation was performed on data from two separate earlier studies, investigating heatshock protein 65 and neopterin in the same population of subjects examined for the presence of carotid atherosclerosis. Both heat-shock protein 65 and neopterin concentrations are significantly correlated with atherosclerosis, but the correlation between both biochemical analytes is low albeit significant. Neopterin, but not heat-shock protein 65 concentrations were shown to be significantly higher in women with presence of antinuclear antibodies, particularly in women older than 65 years of age. This finding seems to explain earlier observations of raised neopterin concentrations in such older women, irrespective of the presence or absence of atherosclerosis.
\end{abstract}

Key words: Neopterin; Heat-shock protein 65, Autoantibodies, Atherosclerosis

\section{Introduction}

Stress or heat-shock protein (hsp) 65 , a highly conserved protein synthesized by almost all cells in response to varying stresses, has been shown to be involved in the pathogenesis of atherosclerosis (1-5). Recently, we reported that serum antibodies to hsp65, but not autoantibodies, were significantly increased in subjects with carotid atherosclerosis in randomly selected normal inhabitants of South Tyrol (4), and these antibodies cross-reacted with a $60 \mathrm{kDa}$ protein homologue present in human atherosclerotic lesions (5).

In this same population, we also found elevated

\footnotetext{
${ }^{\S}$ Author to whom correspondence should be addressed.
}

levels of serum neopterin, a pteridine derivative, in subjects with atherosclerosis (6). Both, hsp65 antibodies and neopterin, are considered as indicators of an involvement of immune reactions. Hence, it was deemed of interest to investigate if a relationship exists between these two variables in atherosclerosis.

Here we report a short synopsis of the data of both independent studies $(4,6)$, aimed particularly at studying the mutual correlation between hsp65 antibodies and neopterin concentrations, and at investigating whether presence versus absence of other autoantibodies determined in these sera (4) exerts an influence on neopterin levels.

\section{Methods}

As explained in the Introduction, data from two 
earlier independent studies on the same population $(4,6)$ were included in this investigation. Subjects were from a community based study (Bruneck Ischemic Heart Disease and Stroke Prevention Study) conducted in the community of Bruneck (province of Bozen/Alto Adige, Italy). Total study population ( $\mathrm{n}$ $=1000$ ) was selected as a $21 \%$ random sample of all inhabitants aged between 40 and 79 years, whereby men and women were selected equally for inclusion into the study on the basis of an age stratified random sampling strategy.

Complete data on hsp65 antibodies, neopterin and autoantibodies, i.e. antinuclear antibodies (ANA), antibodies to thyroglobulin and thyroid microsomal antigens, and rheumatoid factors, were available for 541 subjects (259 female, 282 male), aged 50 through 80 years.

In all individuals, extensive physical and laboratory examinations were performed, and carotid atherosclerosis was assessed by examination of extracranial carotid arteries using a duplex ultrasound system (UM8 Advanced Technology Laboratories, Bothel, WA) with a $10 \mathrm{MHz}$ imaging probe and a $5 \mathrm{MHz}$ Doppler. A plaque scoring system was used for quantifying the extent of carotid atherosclerosis. This score was calculated by adding the maximum thickness of atherosclerotic plaques (in $\mathrm{mm}$ ) on the near and far walls at four imaging sites of both carotid arteries, with plaques being defined as echo structures enchoraging into the lumen of the vessel.

Details regarding recruitement of subjects as well as physical and laboratory determinations are reported in references \#4 and \#6.

Statistical analysis of data was performed using Spearman rank correlation analysis and Mann-Withney U test for comparing distributions of laboratory data in patients with, or without presence of the autoantibodies studied.

\section{Results}

Correlation between atherosclerosis score, hsp65 and neopterin

Serum concentrations of both hsp65 antibodies and neopterin significantly correlated with the occurrence and severity of carotid atherosclerosis : Spearman rank correlation coefficient $r_{s}$ between hsp65 and score was $0.19(\mathrm{P}<0.0001)$, and between neopterin and score, $r_{s}=0.39(P<0.0001)$. Both laboratory variables showed stronger correlation with score in men (hsp65, $r_{s}=0.23$; neopterin, $r_{s}=0.47$ ) than in women (hsp65, $r_{s}=0.17$; neopterin, $r_{s}=0.32$ ).

The correlation between hsp65 antibodies and neopterin levels is weak albeit significantly different from zero $\left(r_{s}=0.19, P<0.0001\right)$. In contrast to the mutal correlation between score, and neopterin and hsp65, however, the direct correlation between neopterin and hsp65 was stronger in women $\left(r_{s}=0.22\right)$ than in men $\left(r_{s}=0.16\right)$.

\section{Effect of other autoantibodies on neopterin and hsp65}

When studying potential effects of other autoantibodies on neopterin and hsp65 concentrations, there was only one striking result : neopterin but not hsp65 concentrations were significantly higher in subjects with high titers $(>1: 50)$ of ANA (Mann-Whitney $\mathrm{U}=10499, \mathrm{P}=0.0091$ ). No correlations were found between hsp65 and neopterin on the one hand, and the other autoantibodies studied on the other hand (details not reported).

Closer inspection showed that ANA effects on neopterin were significant only in women $(P=0.029)$, not in men $(\mathrm{P}=0.22)$. Furthermore, in women there was a significant association between ANA and age, women above 65 years showing a significantly higher frequency of ANA $(\mathrm{P}=0.0004)$ presence than women below this age. In men, no such correlation was detectable.

\section{Discussion}

Both neopterin and hsp65 showed significant correlations with presence of carotid atherosclerosis, as was described earlier $(4,6,7)$. The correlation between both indicators of immune activation, however, is very weak albeit significant due to the relatively large number of individuals investigated. The small correlation coefficient between hsp65 and neopterin levels suggests that both analytes throw light on different aspects of cellular immune mechanisms.

The most significant finding of the present re-investigation of these earlier data is the strong and unexpected effect on neopterin of the presence of ANA, particularly in women. This observation seems particularly interesting since it may provide an explanation for the striking observation in our earlier paper (6) that neopterin was not only significantly correlated with atherosclerosis in older men and in younger men and women, but was also elevated in older women (above $65 \mathrm{yr}$ ) without detectable atherosclerosis. It was speculated (6) that other inflammatory processes could be the underlying cause for this peculiarity. The present finding of a significant positive correlation between neopterin elevation and occurrence of ANA specifically in older women seems to substantiate this concept. 
In conclusion, neopterin and hsp65 antibodies, positively correlated with atherosclerosis, may reflect different aspects of immune reactions in the pathogenesis and/or course of carotid atherosclerosis. The stronger correlation between atherosclerosis score and neopterin as compared to hsp65 antibodies, may be partially caused by common correlation of these both variables with other factors such as, e.g., age, sex and presence of ANA.

\section{References}

1. Xu Q, Kleindienst R, Waitz W, Dietrich H, Wick G. Increased expression of heat shock protein 65 coincides with a population of infiltrating $\mathrm{T}$ lymphocytes in atherosclerotic lesions of rabbits specifically responding to heat shock protein 65. J Clin Invest 1993; 91: 2693-2702.

2. Berberian PA, Myers W, Tytell M, Challa V, Bond MG. Immunohistochemical localization of heat shock protein-70 in normal-appearing and atherosclerotic specimens of human arteries. Am J Pathol 1990; 136: 71-80.

3. Kleindienst $\mathrm{R}, \mathrm{Xu} \mathrm{Q}$, Willeit J, Waldenberger FR, Weimann $\mathrm{S}$, Wick G. Immunology of atherosclerosis: demonstration of heat shock protein 60 expression and $\mathrm{T}$ lymphocytes bearing $\alpha / \beta$ or $\gamma / \delta$ receptor in human atherosclerotic lesions. Am J Pathol 1993; 142: 1927-1937.

4. Xu Q, Willeit J, Marosi M, Kleindienst R, Oberhollenzer F, Kiechl S, Stulnig T, Luef G, Wick G. Association of serum antibodies to heat-shock protein p65 with carotid atherosclerosis. Lancet 1993; 341: 255-259.

5. Xu Q, Leuf G, Weimann S, Gupta RS, Wolf H, Wick G. Staining of endothelial cells and macrophages in atherosclerotic lesions with human heat-shock protein reactive antisera. Arterioscler Thromb 1993; 13: 1763-1769.

6. Weiss G, Willeit J, Kiechl S, Fuchs D, Jarosch E, Oberhollenzer F, Reibnegger G, Tilz GP, Gerstenbrand F, Wachter $\mathrm{H}$. Increased concentrations of neopterin in carotid atherosclerosis. Atherosclerosis 1994; 106: 263-271.

7. Tatzber F, Rabl H, Koriska K, Erhart U, Puhl H, Waeg G, Krebs A, Esterbauer H. Elevated serum neopterin levels in atherosclerosis. Atherosclerosis 1991; 89: 203-208. 